
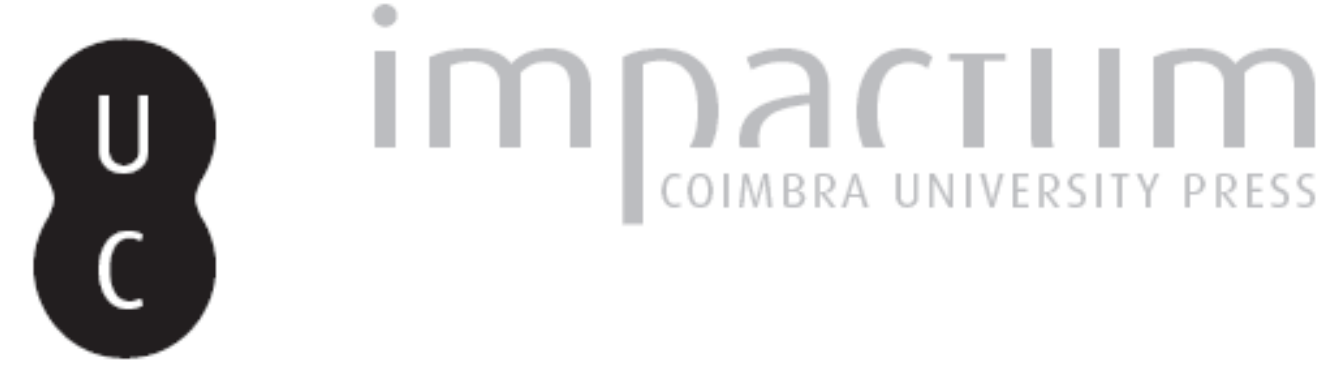

\title{
Os problemas da cartografia dos riscos naturais: contributos para a definição da susceptibilidade geomorfológica a partir da observação de vários movimentos de vertente ocorridos no Norte de Portugal
}

Autor(es): $\quad$ Bateira, Carlos; Abreu, João

Publicado por: Associação Portuguesa de Riscos, Prevenção e Segurança

URL

persistente:

URI:http://hdl.handle.net/10316.2/40073

DOI:

DOI:https://doi.org/10.14195/1647-7723_10_5

Accessed : $\quad$ 26-Apr-2023 11:06:37

A navegação consulta e descarregamento dos títulos inseridos nas Bibliotecas Digitais UC Digitalis, UC Pombalina e UC Impactum, pressupõem a aceitação plena e sem reservas dos Termos e Condições de Uso destas Bibliotecas Digitais, disponíveis em https://digitalis.uc.pt/pt-pt/termos.

Conforme exposto nos referidos Termos e Condições de Uso, o descarregamento de títulos de acesso restrito requer uma licença válida de autorização devendo o utilizador aceder ao(s) documento(s) a partir de um endereço de IP da instituição detentora da supramencionada licença.

Ao utilizador é apenas permitido o descarregamento para uso pessoal, pelo que o emprego do(s) título(s) descarregado(s) para outro fim, designadamente comercial, carece de autorização do respetivo autor ou editor da obra.

Na medida em que todas as obras da UC Digitalis se encontram protegidas pelo Código do Direito de Autor e Direitos Conexos e demais legislação aplicável, toda a cópia, parcial ou total, deste documento, nos casos em que é legalmente admitida, deverá conter ou fazer-se acompanhar por este aviso.

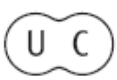




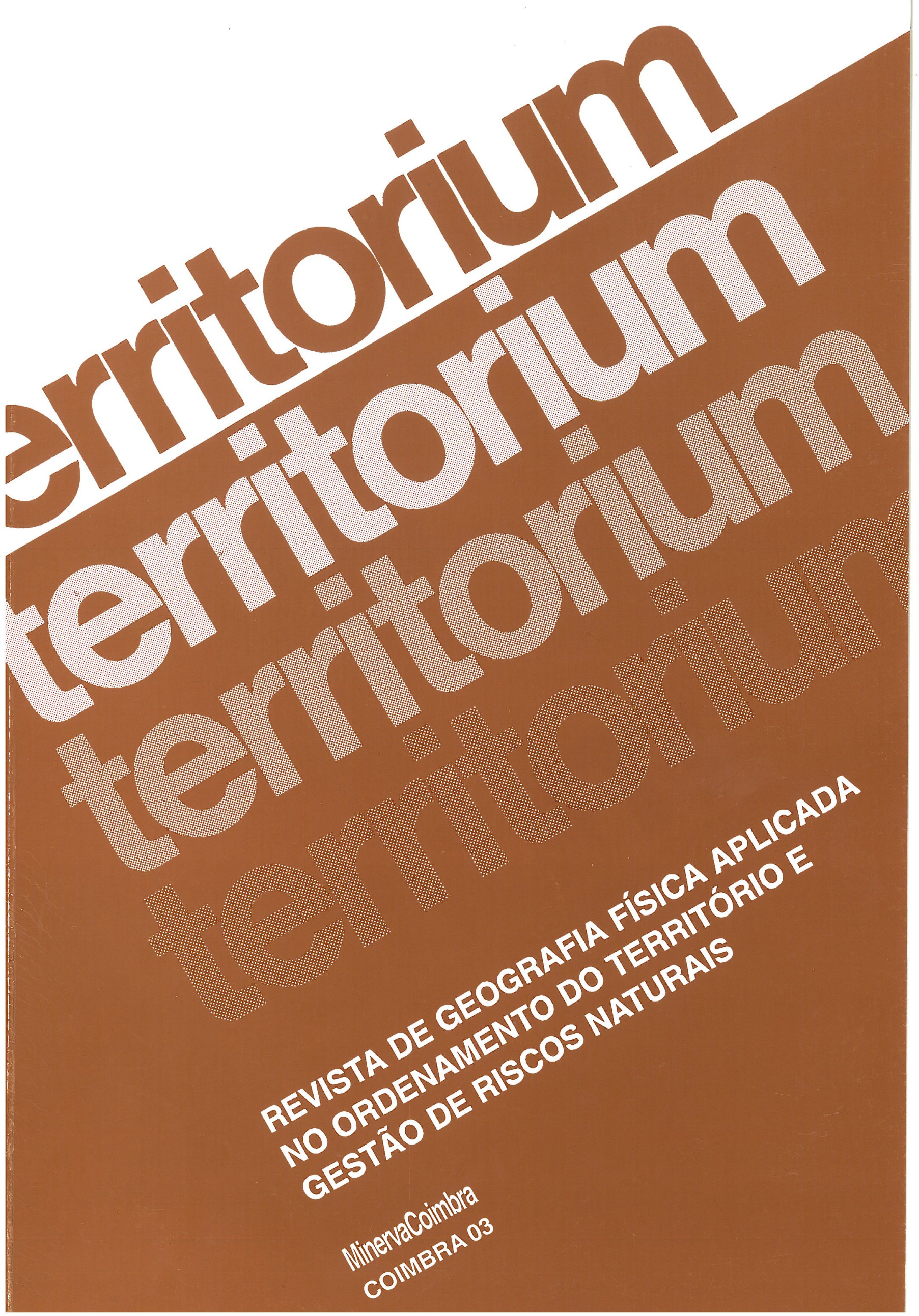




\title{
Os problemas da cartografia dos riscos naturais. Contributos para a definição da susceptibilidade geomorfológica a partir da observação de vários movimentos de vertente ocorridos no Norte de Portugal*
}

\author{
Carlos Bateira* \\ João Abreu**
}

\section{Resumo:}

A produção de cartografia dos riscos naturais relativos a movimentos de vertente depende, em larga medida, do conhecimentos dos factores permanentes. O Inverno de 2000/2001 constitui uma referência importante na definição desses factores uma vez que em várias áreas do Norte de Portugal ocorreram vários tipos de movimentos de vertente, em condições geográficas muito diversificadas. O estudo desses movimentos permite alargar a conhecimento sobre as suas condições de ocorrência e, dessa forma, contribuir para a definição dos critérios de construção da cartografia da susceptibilidade geomorfológica. Quer optemos pela cartografia directa ou indirecta na zonação dos riscos naturais, consideramos que não é possível fazê-lo sem que os critérios que presidem à sua elaboração sejam definidos a partir do estudo das situações de crise ocorridas. Neste texto são apresentados vários movimentos de vertente no norte de Portugal e são analisados os factores geográficos responsáveis pela sua ocorrência. Na apresentação que é feita đá-se importância aos aspectos que se relacionam com a intervenção humana e questiona-se o papel que a cartografia da susceptibilidade geomorfológica poderá ter no ordenamento e planeamento do território.

Palavras chave:

Movimento de vertente, risco natural, cartografia, Norte de Portugal.

\section{Résumé:}

Dans l'hiver de 2000/2001, au Nord du Portugal, une grande quantité de mouvements de versants s'est développée. L'étude de ces mouvements et des conditions géographiques de leur occurrence, ont permis l'obtention d'une large quantité d'information indispensable à l'étude de la susceptibilité géomorphologique aux mouvements de versants. La connaissance des facteurs d'occurrence des mouvements de versants est indispensable, au delà de l'usage des méthodes de cartographie directe ou indirecte. Dans cette communication sont présentés plusieurs motvements et on analyse les facteurs géographiques de leur occurrence. On présente aussi l'importance de l'activité humaine pour le développement des mouvements de terrain et ses implications dans l'élaboration de la cartographie des risques naturels.

Mots clés:

Mouvements de versants, risques naturels, cartographie, Nord du Portugal.

\section{Abstract:}

The winter of 2000/2001, at North of Portugal, developed a large quantity of mass movements. The study of those movements, specially the geographic factors of its occurrence, is an important source of information to define the main criteria of geomorphological susceptibility to mass movements. Both, direct or indirect cartography of natural hazards cannot be built without a deep knowledge of these factors. In this paper are presented several of this movements and are analysed the geographic factors that contributed to their occurrence. The importance of human activity on the environment is discussed and the changes that contribute for the occurrence of mass movements are analysed, as well as its importance to the elaboration of the cartography of natural hazards.

Key words:

Mass movements, natural hazards, cartography, North of Portugal.

\section{Introdução}

Antes do inverno de 2000/2001 as notícias de ocorrências de instabilidade de vertentes na região norte de Portugal eram esporádicas e tinham merecido poucas referênciaș na bibliografia científica portuguesa sobre esta matéria (A. B. FERREIRA e J. L.ZÊZZERE, 1997). Oinvernode 2000/2001 constitui uma referência importante para os estudos dos movimentos de vertente no Norte de Portugal. Essa referência resulta de duas circunstâncias:

\footnotetext{
* Texto elaborado com base na apresentação feita no IX Encontro sobre Riscos Naturais, Coimbra, 22.11.2002.

** Departamento de Geografia da Fac. Letras da Universidade do Porto - c.el.: cbateira@letras.up.pt

*** T'écnico superior da Câmara Municipal de Gaia.
}

- vários tipos de movimentos de vertente ocorreram em áreas de forte diversidade morfo-estrutural $\mathrm{e}$,

- muitos dos movimentos provocaram elevadíssimos prejuízos materiais e vítimas mortais, o que conferiu um grande mediatismo a várias destas ocorrências.

O conjunto de acontecimentos ocorridos ao nível da dinâmica do meio físico (tanto ao nível da evolução de vertentes como da dinâmica fluvial) permitiram lançar a ideia da necessidade urgente de produção da cartografia de riscos naturais. Ao nível municipal constata-se que o quadro legal que rege a delimitação das áreas de riscos naturais no âmbito do ordenamento do território falhou. Esta urgência exige que os critérios geomorfológicos de definição das áreas de forte risco de movimentos de vertente sejam 
sistematizados. Neste contexto, os movimentos de vertente ocorridos no inverno de 2000/2001 forneceram novos elementos relativos à dinâmica do meio físico e permitiu o registo de vários factores de risco até então negligenciados na análise do risco natural.

Importa referir que, dada a urgência de produção de cartografia dos riscos de movimentos de vertente e o carácter moroso da sua elaboração, recorre-se frequentemente à cartografia indirecta. Esta metodologia exige o conhecimento profundo da dinâmica do meio físico das áreas que se pretende cartografar assim como dos factores permanentes que condicionam a ocorrência de movimentos de vertente. $\mathrm{O}$. inverno de 2000/2001 permitiu apurar a leitura do conjunto de factores permanentes responsáveis pela definição da susceptibilidade geomorfológica a movimentos de vertente. A elaboração da cartografia dos riscos naturais pelo método da cartografia indirecta revela-se bastante expedita mas terá que ser revista com base nos novos registos feitos a partir dos. movimen tos de vertente ocorridos no referido inverno.

\section{Percursos metodológicos. Breve referênCia}

M. PANIZZA (1990), apresentou dois grandes conjuntos de procedimentos para a análise do risco natural: a cartografia directa e a cartografia indirecta. Em Portugal, J. L. ZÊZERE (1997) apresenta uma síntese sobre o conjunto de autores que dedicam a sua investigação à utilização de diversos métodos de cartografia dos riscos naturais e discute as dificuldades e problemas que lhe estão inerentes.

\section{O registo da dinâmica geomorfológica}

O primeiro baseia-se no registo de todos os indícios que resultam da dinâmica geomorfológica, tanto os que ainda permanecem visíveis no terreno, com ou sem evolução posterior, ou ainda, os que são precursores de movimentos. Estes registos, por vezes recorrendo a documentos históricos, só podem ser elaborados com recurso ao levantamento de campo e à construção de cartografia geomorfológica de pormenor onde é dada preferência ao registo da dinâmica actual. O rigor deste método depende em larga medida da experiência do operador e do conhecimento que possui do conjunto de processos geomorfológicos dominantes na área de trabalho, revelando-se muito moroso.

A cartografia directa, com recurso ao levantamento geomorfológico, tem-se revelado pouco eficaz sobretudo em áreas onde as cicatrizes dos movimentos de vertente apresentam uma evolução muito rápida, sendo difícil identificar as áreas de erosão e de alimentação dos processos de evolução de vertente.
Essa dificuldade é particularmente sentida nas áreas de afloramento de granitóides, sobretudo quando os mantos de alteração apresentam grande espessura propiciando uma forte evolução geomorfológica posterior à ocorrência de movimentos de vertente. Por vezes, só com recurso ao registo de vários indícios de movimentação de vertentes se poderá ultrapassar as dificuldades da cartografia directa a saber: documentação histórica, depósitos de vertentes e correspondente comparação com a morfologia de movimentos de vertentes conhecidos e que experimentaram forte evolução posterior.

\section{A análise integrada}

Outro método, porventura complementar, consiste na inventariação e análise das condições de ocorrência de movimentos de vertente e cartografar as áreas onde se registam essas condições. Isso permite desenvolver a cartografia dos factores responsáveis por essa evolução de vertentes. Uma vez constituída a cartografia é possível delimitar áreas de diferente susceptibilidade geomorfológica a movimentos de vertente. Com este método procede-se à generalização dos factores de ocorrência de movimentos de vertente a sectores de dinâmica geomorfológica semelhante, embora ainda não tenham qualquer tipo de indício de instabilidade, o que pode significar uma simplificação e generalização nem sempre fácil de controlar.

A análise integrada dos factores de ocorrência de movimentos de vertente exige a sua definição clara. Porém, essa definição supõe que as condições de ocorrência estejam previamente estudadas e sejam do conhecimento dos construtores da cartografia. Essa definição comandará a organização dos critérios que presidem à definição do zonamento das áreas de maior susceptibilidade geomorfológica. É, portanto, suposto que haja investigação prévia, conhecimento do território e análise de casos concretos verificados na área de trabalho que permita generalizar de forma coerente o conjunto de factores responsáveis pela ocorrência de movimentos de vertente e respectiva ponderação.

\section{Cartografia directa}

\section{Indicadores de carácter histórico}

\section{O fluxo de detritos de S. João (Melgaço)}

Ofluxo de detritos de S. João constitui um exemplo já documentado por nós (C. BATEIRA et al., 1997). Em 1841, foi registado um movimento que destruiu um aldeia e teve um impacto muito forte na economia 
local. Os únicos vestígios de que dispomos para reconstituir o processo correspondem às notícias de alguns periódicos da época, a morfologia da vertente junto à cicatriz provável, em forma de concha, e a base da vertente em forma de cone de dejecção. Na base da vertente é possível observar um depósito que se estende por todo vale denunciando coalescência de deposições resultantes de vários movimentos. A correlação do movimento conhecido pelas notícias e memória popular com o depósito da base da vertente sugere que a geomorfologia do vale é recente, sendo ainda activa (fig. 1 e fots. 1 e 2 ). Paralelamente registamos, com base na tradição popular, um conjunto de elementos de referência que são testemunho da dinâmica do movimento de vertente. A Igreja do lugar permanece semi-soterrada e foram construídos vários elementos de carácter religioso com o objectivo de relembrar as vítimas.

O facto de já terem decorrido mais de 160 anos sobre o fluxo de S. João poderia cimentar a ideia de que o processo estaria estabilizado e a vertente não constituiria área de elevada susceptibilidade geomorfológica a movimentos de vertente, mesmo que de fraca probabilidade de ocorrência. O inverno de 2000/2001

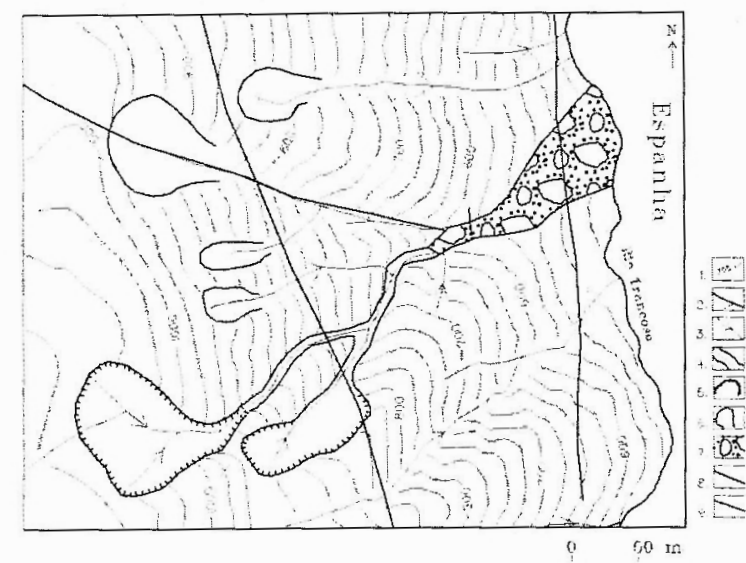

Fig. 1 - Esboço geomorfológico de S. João (Porto Carreiro). Ainda é possivel observar as bacias de recepção dos barrancos, provavelmente herdadas das áreas de arranque dos movimentos de vertente.

1.Curva de nível. 2. Curso de água. 3. Barranco. 4. Canal de transporte. 5. Cicatriz principal. 6. Cicatriz provável. 7. Cone de dejecção. 8. Falha. 9. Falha provável.

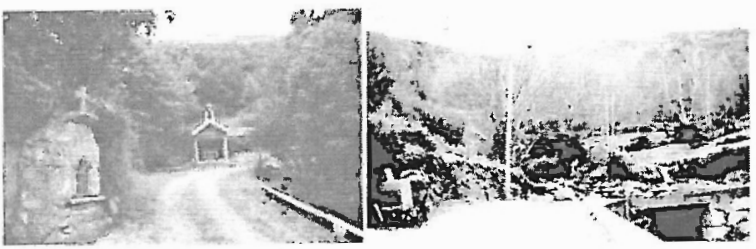

Fotos 1 e 2 - Aspecto parcelar da área afectada pelo fluxo de detritos de S. João em 1841 e 2001 . A capela, em segundo plano, construída em memória dos mortos foi destruída pelo novo fluxo, em 2001 . permitiu confirmar a importância dos registos históricos na definição das áreas de forte susceptibilidade geomorfológica a movimentos de vertente. Com efeito, nesse inverno, a capela construída em memória dos mortos do fluxo ocorrido em 1941 foi destruída por um novo fluxo, desta vez de menores dimensões.

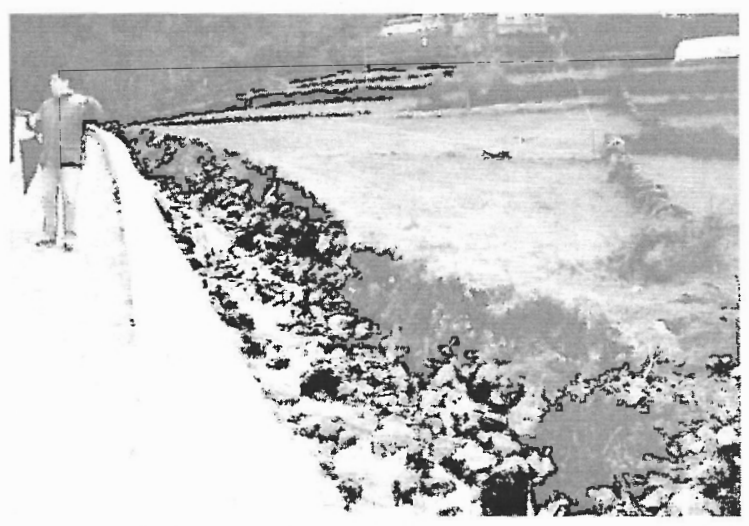

Foto 3 - Vista parcial do cone de dejecção onde está instalado o lugar de Porto Carreiro. $O$ caminho que acompanha a linha de água teve de ser refeito devido a destruição resultante do fluxo de detritos ocorrido em 2001. Fotografia de João Ferreira, discente do curso de Geografia da FLUP.

Este exemplo demonstra que, apesar de intervalos de ocorrência muito dilatados, as condições geomorfológicas de ocorrência do fluxo de detritos de S. João permanecem. O movimento poderá permanecer dormente durante mais de século e meio, sendo reactivado desde que haja condições hidro-meteorológicas capazes de conduzir a uma nova ruptura na vertente.

O fluxo de detritos de S. João permite identificar as condições favoráveis a movimentos de vertente no vale do rio Trancoso e estabelecer uma relação entre depósitos que colmatam o fundo de vale, encaixe da rede hidrográfica (pequenos valeiros de forte declive longitudinal) eáreas côncavas na parte superior das vertentes. O caso do fluxo de detritos de S. João confirma a importância da identificação destas áreas na definição da susceptibilidade geomorfológica, mesmo que não hajam testemunhos históricos.

\section{Indícios de movimentos de vertente no Ermelo (Gerês)}

Uma outra situação semelhante é possível observar-se no Ermelo (Gerês). Neste caso observa-se o mesmo tipo de encaixe da rede hidrográfica, a mesma concavidade no topo da vertente e uma importante acumulação de blocos, em forma de cone, no leito menor do rio Lima. Neste caso, os materiais depositados na base da vertente foram lavados pela erosão fluvial permanecendo os materiais grosseiros (fot. 4). 


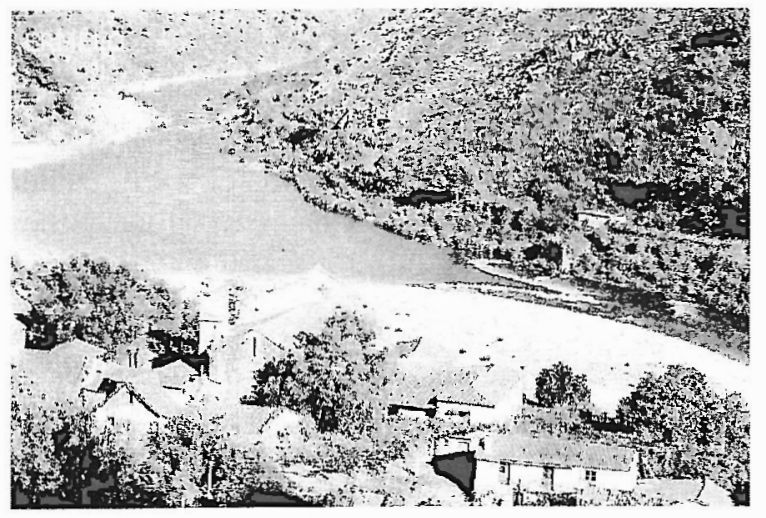

Foto 4 - Lugar do Ermelo. Observa-se no leito menor grande acumulação de blocos resuitante da dinâmica de vertente, posteriormente lavados pelo escoamento fluvial.

O mosteiro do Ermelo apresenta dois sinais que põem em evidência a destruição por efeito de algum qualquer desastre, e reconstrução posterior. A rosácea, que constitui um dos elementos ornamentais mais imponentes do mosteiro, está parcialmente encoberta por uma recuperação posterior, denunciando uma imponência que não coincide com a construção actual. Por outro lado, as arcadas laterais do mosteiro estão parcialmente destruídas e soterradas, à semelhança do que ocorre na Igreja de Porto Carreiro (S. João).

Hoje nãoé possível observar o depósito de vertente que poderá ter resultado do(s) provável(eis) movimento(s) de vertente. A albufeira da barragem do Ermelo não permite esse estudo. Porém, um postal da localidade do Ermelo antes da construção da barragem apresenta uma visão do fundo do vale onde é possível verificar uma importante acumulação de blocos no leito menor, o que provoca o desvio do escoamento para a margem oposta. Essa acumulação de blocos terá resultado do movimento ou movimentos de vertente ocorridos no Ermelo. A lavagem dos materiais finos desse depósito terá sido feita pelo cursode água, que nãotem competência para transportar os materiais grosseiros.

Também aqui se põe em evidência os indícios geomorfológicos muito semelhantes aos do movimento de S. João, embora não tenhamos a confirmação por documentos históricos ${ }^{(1)}$.

\section{Indicadores sedimentológicos}

Um dos testemunhos mais evidentes da dinâmica geomorfológica relacionada com os movimentos de vertente são os depósitos que dela resultam. Em áreas de forte ocupação humana rapidamente são

(1) A pesquisa histórica permitiu concluir que o mosteiro sofreu importantes danos o que terá contribuído para o declínio da vida religiosa no Ermelo, mas não é possível confirmar que isso se deveu a um desastre natural, embora não exclua essa hipótese apagados os vestígios, tanto dos materiais depositados mas, sobretudo, da cicatriz, com recurso a terraplanagens e a aterros ${ }^{(2)}$. Porém, frequentemente, é possível observar depósitos de vertente que, pelas suas características sedimentares, sugerem origem em movimentos de vertentes. Por vezes, o volume e a dimensão dos materiais movimentados é de tal modo grande que evidencia uma prolongada evolução geomorfológica. É o caso do depósito do Ermelo (Alvão).

\section{Depósito do Ermelo (Alvão)}

Este depósito é muito semelhante aos depósitos que resultam dos fluxos de detritos (fot. 5). Éconstituído por matriz de textura grosseira, sendo muito heterométrico e sem qualquer indício de triagem promovida por escoamento fluvial ou mesmo fluvio-torrencial. Estes sedimentos colmatam o fundo do vale extremamente encaixado do Rib $^{\circ}$ do Sião (fig. 2 ). As vertentes apresentam um declive muito forte dispondo-se em extensos anfiteatros muito semelhantes a cicatrizes múltiplas de movimentos de vertente. A composição litológica dos elementos grosseiros do depósito é diversa sendo possível identificar o granito de grão médio de Vila Real, quartzitos, xistos, filitos e grauvaques. Estes mesmos elementos litológicos constituem a estrutura do topo das vertentes, sugerindo evidente fonte de alimentação do depósito (C. BATEIRA, 2001).

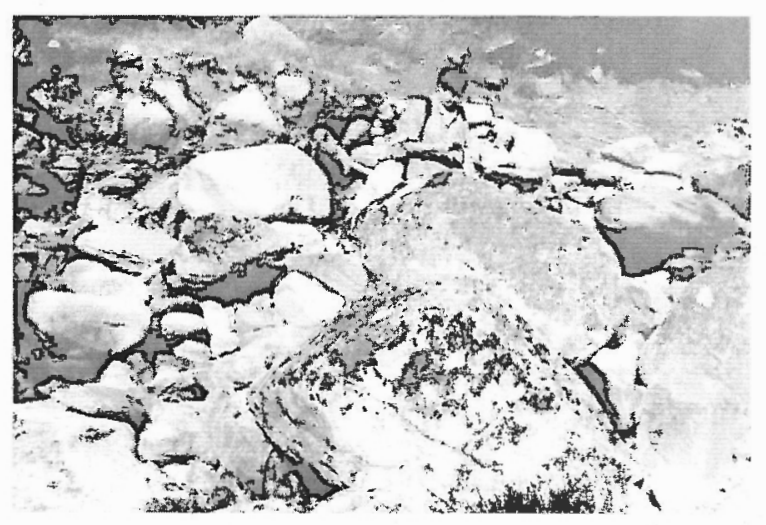

Foto 5 - O fundo do vale do rib ${ }^{\circ}$ de Sião está colmatado por depósito de vários metros de espessura (Alvão).

A morfologia do vale e os elementos sedimentológicos são indicadores de uma importante evolução geomorfológica relacionada com movimentos de vertente de duração prolongada. A semelhança sedimentar deste depósito com os que resultam de fluxos de detritos conhecidos, aliada às características geomorfológicas das vertentes do vale do rib $^{\circ}$ do

(2) Grande parte dos movimentos de vertente que afectaram o Marão em Janeiro de 2001 já não são observáveis devido aos trabalhos de recuperação das propriedades afectadas. 


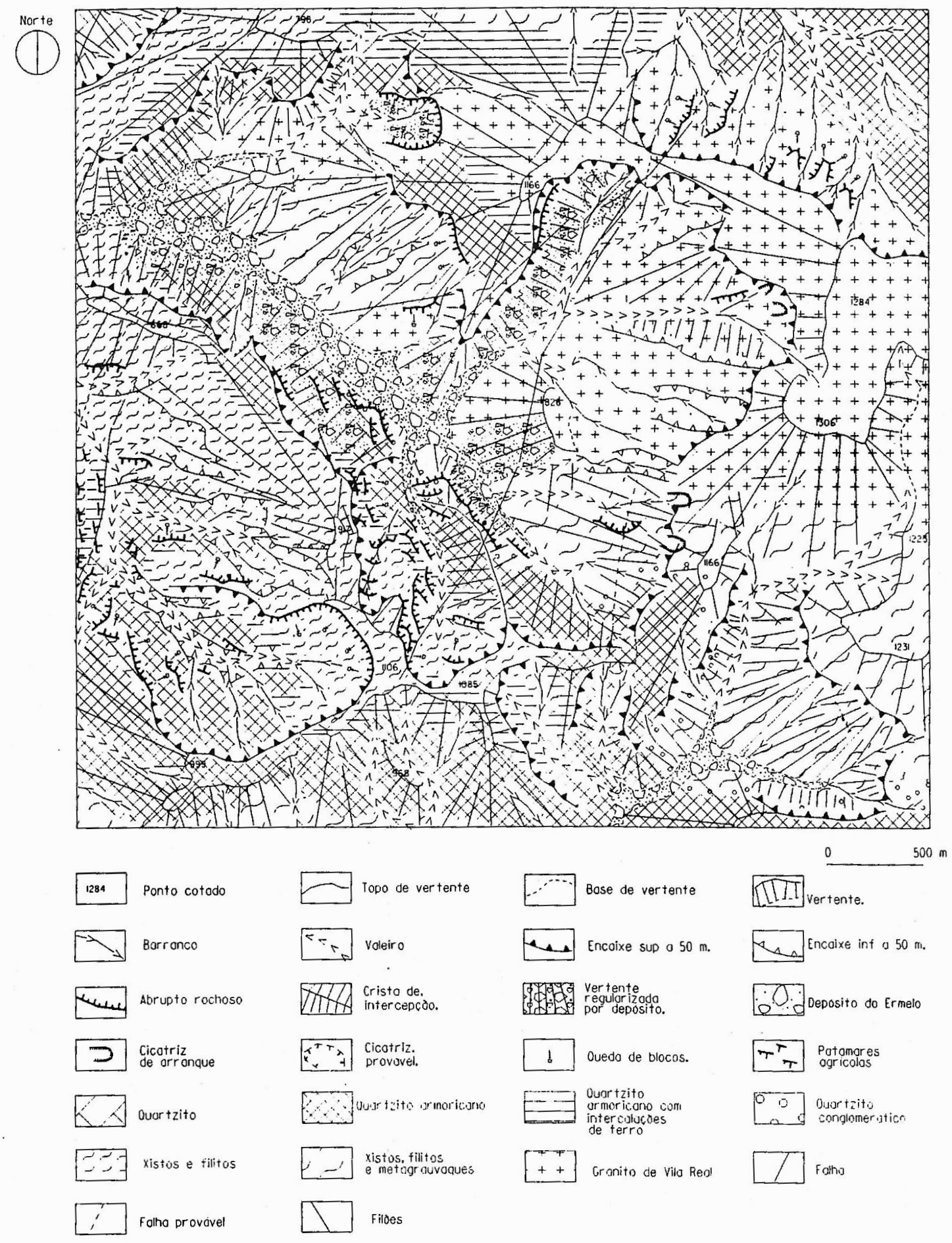

Fig. 2 - Esboço geomorfológico do rib ${ }^{0}$ de Sião (Ermelo - Alvão). 
Sião e à posição topográfica colmatando o fundo do vale, permitem-nos afirmar que estamos na presença de um importante depósito que resultou da evolução de vertente por fluxos de detritos de idade recente. Este depósito é testemunho da evolução de vertentes característica de ambiência paleoclimática mais húmida que a actual (tardi-glaciar?) $)^{(3)}$. É provável que, na actualidade, e em situações extremas, os mesmos processos de evolução de vertente sejam retomados (G. COUDÉ-GAUSSEN, 1981).

A cartografia destes depósitos é essencial por duas razões: por um lado estes depósitos são testemunho de uma importante evolução de vertentes que em situações meteorológicas excepcionais se poderá repetir; por outro lado, permitem identificar as características geográficas que propiciaram esta evolução de vertentes e, desse modo, permite a definição de áreas de forte susceptibilidade geomorfológica a movimentos de vertente.

Ao longo das serras do NW Português é possível identificar depósitos deste tipo ${ }^{(4)}$ (C. BATEIRA, 2001).

\section{Indicadores da dinâmica geomorfológica actual}

Os movimentos ocorridos dão-nos elementos preciosos para o desenvolvimento dos estudos dos factores de ocorrência e das situações geográficas passíveis de desenvolverem uma evolução geomorfológica por movimentos de vertente.

\section{As bacias hidrográficas de primeira ordem}

Uma parte significativa dos movimentos de vertente ocorridos no Norte de Portugal durante o inverno de 2000/2001 desenvolveram a cicatriz de arranque em bacias hidrográficas de primeira ordem (segundo Strahler). Em Arcos de Valdevez podem ser observados dois destes movimentos: em Frades ${ }^{(5)}$ (fot. 6) e S. Vicente ${ }^{(6)}$ (fot. 7). Em áreas de montanha estas bacias hidrográficas de primeira ordem apresentam declives extremamente acentuados sendo, em geral, superiores a $30^{\circ}$.

Ambos os movimentos desenvolvem-se a expensas de mantos de alteração granítica de fraca espessura. $\mathrm{Na}$ área da cicatriz, o total do manto de alteração e do depósito pelicular de carácter solifluxivo que o cobre,

(3) Datagens em $\mathrm{C}^{14}$ feitas em depósito semelhantes na serra do Marão apontain para uma data em torno dos $18000 \mathrm{BP}$ (A. PEDROSA, 1997).

(4) O mesmo tipo de depósito é observável na $S^{\mathbf{a}}$ da Graça (Cabeceiras de Basto).

(5) Este movimento de vertente ocorreu em 7 de Dezembro de 2000, tendo sido amplamente divulgado pelos media, e originou a destruição de várias casas e a morte de quatro pessoas.

(6) O movimento de S. Vicente (Rio Frio) provocou a destruiçăo de uma habitação.

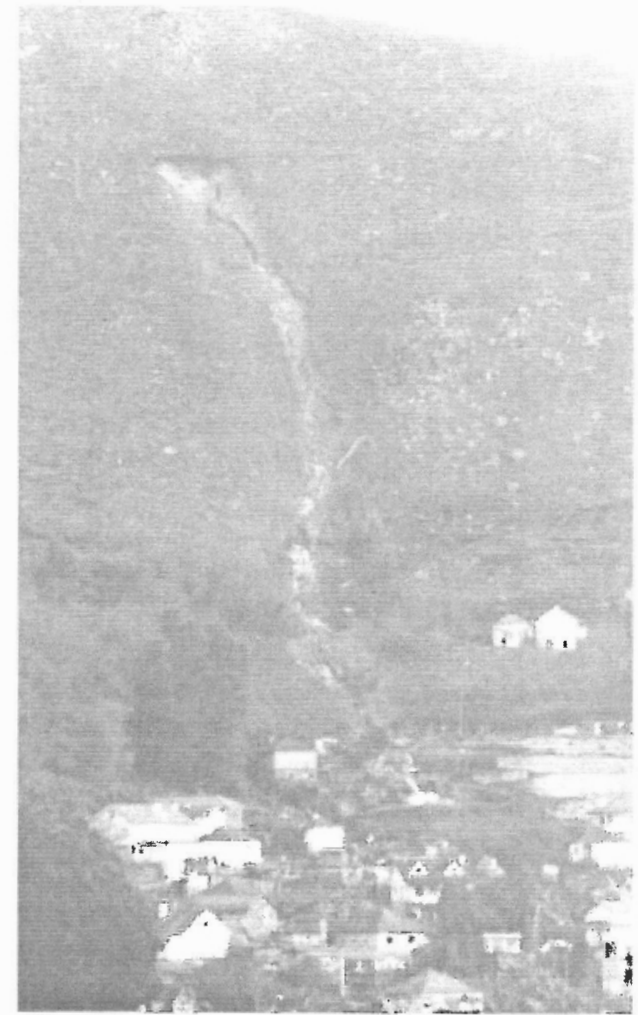

Foto 6 - Fluxo de detritos de Frades (Arcos de Valdevez)

têm uma espessura pelicular de cerca de dois metros. As cicatrizes coincidem com a frente de alteração (contacto entre o manto de alteração e o granitóide subjacente) que constitui a superfície de deslizamento. Este aspectoé particularmente evidente no movimento de Frades (fig. 3), em que esta superfície coincide com os planos de fracturação que orientam o processo de alteração química da rocha.

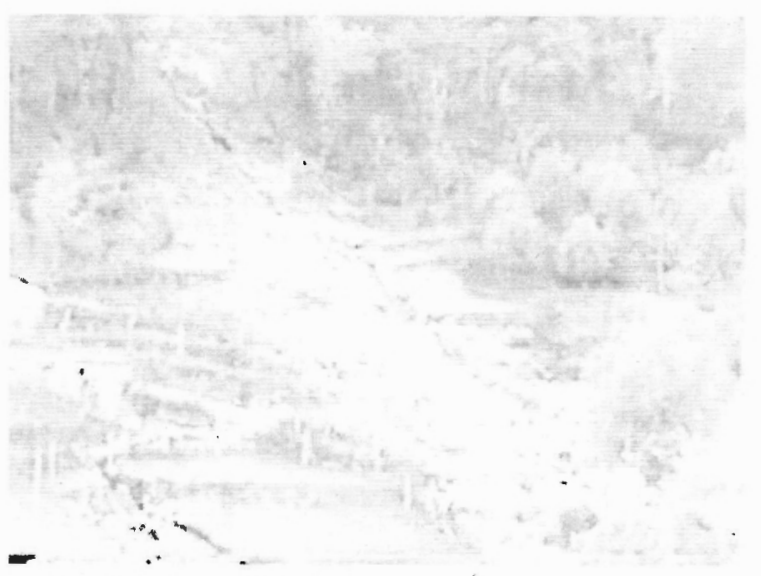

Foto 7 - Fluxo de detritos de Rio Frio (Arcos de Valdevez).

O quadrado corresponde à localização de uma habitação destruída. Uma parte muito significativa dos materiais movimentados transformou-se em carga sólida do curso de água, percorrendo ainda uma distância de cerca de $3 \mathrm{~km}$. 


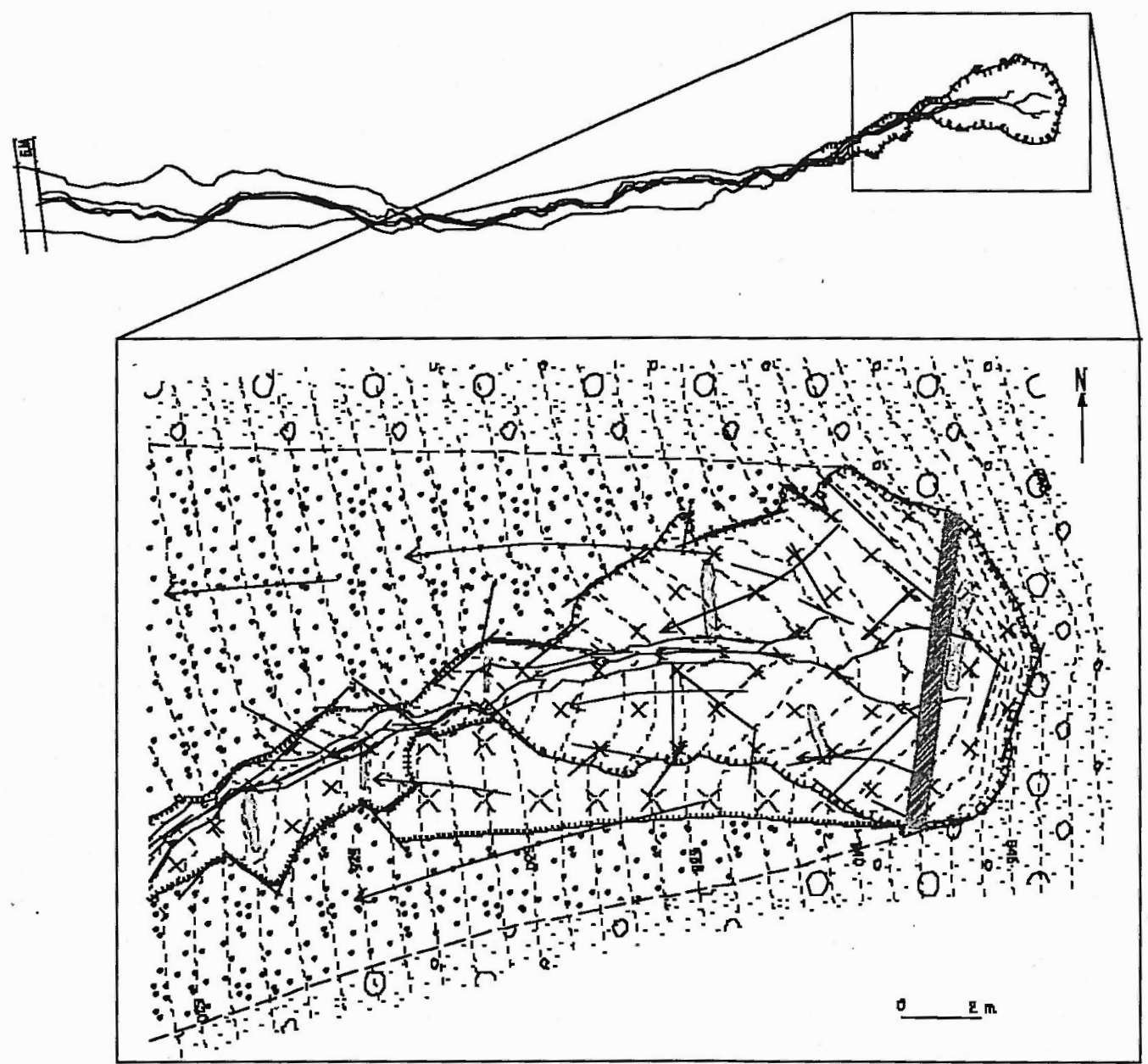

\section{Lagontix}

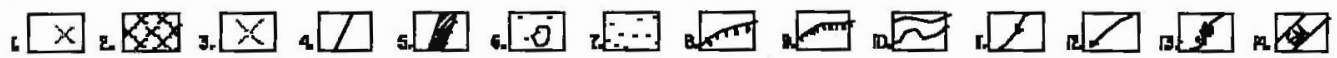

Fig. 3: Esboço geomorfológico da cicatriz principal do fluxo de detritos de Frades (Arcos de Valdevez).

1. Granito da Serra Amarela. 2. Granito do Extremo. 3. Arenas de estrutura conservada. 4. Diáclase. 5. Caixa de falha. 6. Depósito de vertente, com características solifluxivas, de grande heterometria. 7. Cobertura pelicular argilosa residual na áreas de transporte do fluxo. 8. Cicatriz principal. 9. Cicatriz secundária. 10. Limite da ravina, funcional no período imediato ao fluxo. 11. Ravinas na superfície de rotura. 12. Direcção da deslocação dos materiais movimentados. 13. Curva de nível. 14. Estrada Municipal.

\section{Mantos de alteração de pequena espessura}

A espessura pelicular do manto de alteração representa umelemento essencial na drenagem subsuperficial das vertentes. Na parte superior as espessuras do manto de alteração são quase sempre diminutas, em virtude da maior intensidade erosiva a que estes materiais estão sujeitos. Por outro lado, a capacidade de infiltração e conductividade hidráulica é consideravelmente elevada, o que permite uma fácil e rápida circulação hídrica (M. SILVÉRIO, 2000) ${ }^{(7)}$. Este

(7) Ver também relatório final doprojecto de investigação "Processos Erosivos no Norte de Portugal: definição de áreas de risco". Equipa: A Pedrosa, C. Bateira, L. Soares e M. Silvério. FCT, 2000. facto dificulta a saturação dos materiais e consequente instabilidade das vertentes. Porém, em ambos os movimentos o processo de circulação da água no manto de alteração é bloqueado.

Em Frades a cicatriz é atravessada por uma caixa de falha, de forte componente argilosa, com espessura de aproximadamente $60 \mathrm{~cm}$, de direcção N-S, e pendor inverso relativamente à forma da vertente. Em S. Vicente a vertente é atravessada por vários filões de aplito, muito alterado, sendo que alguns apresentam espessuras de vários decímetros. Também neste caso, a disposição dos filões é inversa relativamente à vertente. Tanto a falha referida em Frades como os filões referidos em $\mathrm{S}$. Vicente constituem 
obstáculos evidentes à fácil circulação hídrica nos mantos de alteração o que permitiu a saturação rápida do contacto entre o manto de alteração e o substracto rochoso pouco permeável.

De uma forma geral, podemos dizer que as bacias hidrográficas de primeira ordem constituem áreas de convergência da drenagem subsuperficial. Essa convergência permite a concentração do escoamento, sobretudo junto dos contactos entre o manto de alteração e a rocha mãe, muitopouco permeável (A-C. PERRUSSET, 1976 e J. E. COSTA, 1984). Quando existe o efeito de bloqueio à drenagem provocado por uma faixa argilosa (resultante de uma caixa de falha ou de filão de aplito alterado) temos boas condições para o desenvolvimento de forte saturação da parte inferior do manto de alteração que provocou os fluxos de detritos. Este conjunto de condições geomorfológicas dá origem a movimentos superficiais, do tipo dos fluxos, que se inicia por um pequeno deslizamento translacional, o que origina a formação da cicatriz. Uma vez iniciado o movimento, os materiais adquirem uma elevada energia resultante dos fortes declives em que se situam as bacias hidrográficas de primeira ordem em regiões de montanha, desenvolvendo um percurso de transporte de materiais. Nesse percurso é dividido em duas áreas. Na parte central mobiliza mais material, escavando uma ravina, posteriormente utilizada para escoamento superficial concentrado. Nos bordos, desloca-se o material fino, quase liquefeito, sobre os materiais que constituem a vertente, sem qualquer efeito de escavamento, mas ainda com forte potencial destruidor.

O elevado declive aliado à fraca espessura do manto de alteração origina um movimento superficial e de grande velocidade. $O$ poder erosivo e destruidor resulta desta dinâmica associada ao conjunto de materiais grosseiros (blocos que estão disponíveis no depósito de vertente e no manto de alteração) que são mobilizados ao longo do movimento.

\section{Arranjo das vertentes em patamares ao longo das linhas de água}

Geralmente considera-se que os barrancos e os valeiros de forte encaixe se apresentam como áreas de grande susceptibilidade geomorfológica, em especial no que se refere aos movimentos de vertente. Já se conheciam alguns exemplos de fluxos de detritos que se desencadearam ao longo de barrancos em vertentes de forte declives ${ }^{(8)}$ (C. BATEIRA et al., 1995). Contudo, estes barrancos são, frequentemente, organizados em patamares agrícolas. O arranjo para

\footnotetext{
(8) Em 1981, em Arosa (Cavez - Cabeceiras de Basto) ocorreu um fluxo de detritos que destruiu um café e matou 15 pessoas (C. BATEIRA e L. SOARES, 1995).
}

a prática da agricultura, mesmo que de subsistência, implica uma importante alteração das condições de escoamento interno superficial ao longo das vertentes. A construção dos patamares conduz à criação de áreas planas ou de fraco declive, de taludes artificiais de forte inclinação, com ou sem apoio murado e à alteração da estrutura dos materiais que constituem esses patamares por efeito da mobilização feita durante a sua construção.

Enquanto as práticas agrícolas são mantidas, a drenagem das áreas planas está assegurada pelos agricultores durante a estação húmida, bem como são conservadas as estruturas de manutenção dos taludes que os limitam. Contudo, quando existe o abandono agrícola, e não são asseguradas as práticas de drenagem dos terrenos ao longo da estação húmida,
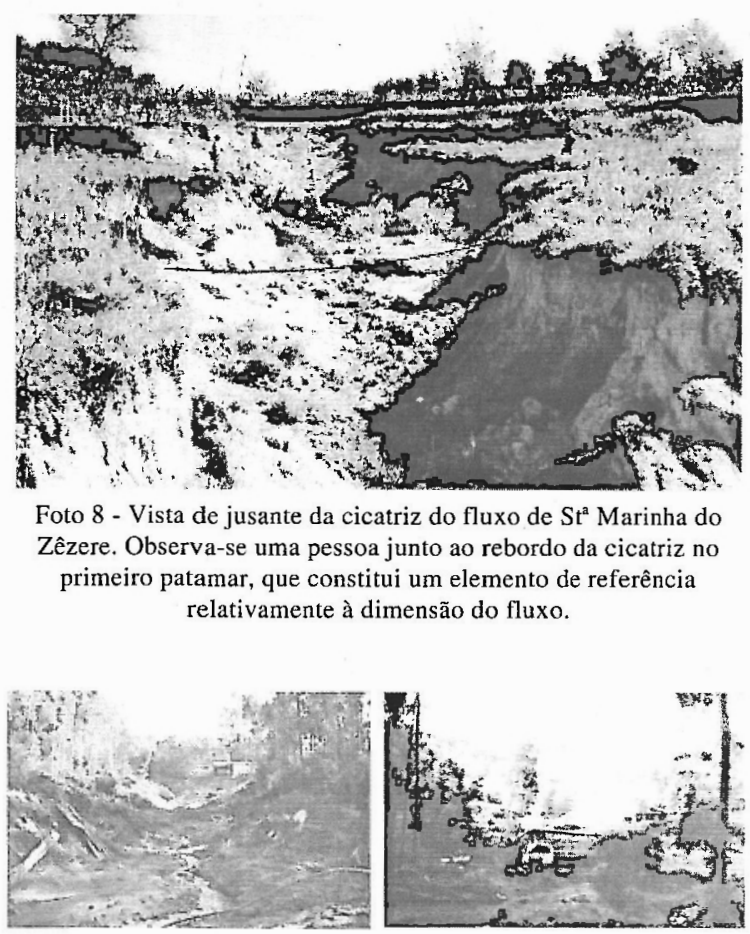

Foto 9 e 10 - Fluxo de lama de Argoncilhe $\mathrm{St}^{\mathrm{a}}$ Maria da Feira), vista de jusante. Ao fundo, à esquerda, é visível o armazém parcialmente destruído. $\grave{A}$ direita, vista parcial da área de acumulação, Observa-se um veículo pesado que se situava no aterro que era utilizado para parque de estacionamento.

todo o processo de drenagem permite uma forte infiltração nos patamares de fraco declive, tornando muito fácil a saturação dos materiais que os constituem.

O estudo detalhado do fluxo de lama de $\mathrm{St}^{\mathrm{a}}$ Marinha do Zêzere identificou ${ }^{(9)}$, ao nível dos materiais que constituem os patamares agrícolas, as linhas gerais da circulação da água. Nestes casos,

(9) O fluxo de Lama de $\mathrm{St}^{2}$ Marinha do Zêzere ocorreu em Janeiro de $2001 \mathrm{e}$ foi objecto de apresentação de um painel, estando em fase de preparação de uma comunicação. 
com a destruição da estrutura dos materiais que constituem a vertente, por efeito da construção do patamar agrícola, a circulação hídrica interna processase por eixos preferenciais que acabam por convergir para a parte central do barranco onde se desenvolve o processo mais importante de concentração da água. A circulação interna aproveita a diferenciação de compactação dos materiais ṕara definir esses eixos de circulação. A água circula muito rapidamente ao longo desses eixos em detrimento da circulação por transferência de água entre partículas. No período imediatamente posterior ao movimento observou-se o desenvolvimento do escoamento superficial generalizado a todos os patamares agrícolas e, ao longo da cicatriz, existiam várias nascentes, fruto da conversão do fluxo interno saturado em fluxo superficial. Isso resultou da total saturação dos materiais constituintes das vertentes.

O fraco declive da área afectada faz realçar a importância das condições de circulação hídrica interna nos materiais destes patamares em detrimento da inclinação da superfície topográfica. A construção dos patamares agrícolas representa uma forte alteração da morfologia propiciando o aumentoda capacidade de infiltração nas áreas planas, para além da alteração da relação entre forças tangenciais e forças de atrito ao longo das taludes artificiais que bordejam os patamares. Esta alteração permite que áreas de declives moderados e moderados a suaves possam experimentar movimentos de vertente com a dinâmica dos fluxos de lama. Nestas circunstâncias é da maior importância a análise da intervenção humana nomeadamente no que se refere à alteração significativa das condições hidro - geomorfológicas do processo de escoamento nas vertentes.

Hoje, à semelhança do que ocorreu em Arosa (Cavez), já não é possível observar a cicatriz do movimento de lama de $\mathrm{St}^{\mathrm{a}}$ Marinha do Zêzere. A reconstrução dos patamares nas áreas de boa rentabilidade das explorações agrícolas é rápida, apagando os vestígios das cicatrizes e dos muros destruídos. Muitos dos movimentos de vertente ocorridos no Marão em Janeiro de 2001 já não são observáveis. Mesmo o movimento complexo de Armamar ${ }^{(10)}$ (2 de Janeiro de 2003) já foi sujeito a obras de regularização e estabilização. À excepção dos de muito grande dimensão, onde ainda é possível observar a cicatriz (Cidadelhe, Ariz), ou em áreas sem explorações agrícolas, a retoma da actividade económica das áreas afectadas destruiu os indícios de instabilidade das vertentes (o mesmo acontece em Alvações do Corgo).

(10) Este movimento foi objecto de estudo detalhado por I. Gomes estando o trabalho em fase de publicação.

\section{Construção de aterros}

Para além dos movimentos de vertente que ocorrem em barrancos organizados em patamares agrícolas, onde a intervenção humana promove o arranjo dos materiais que existem na vertente, assume particular importância as situações em que se constróem patamares fazendo aterros de materiais adicionados à vertente. Esta situação é cada vez mais frequente e resulta da necessidade de espaços mais amplos para construção de infra-estruturas relacionadas com a actividade industrial, comercial ou de vias de comunicação. Os exemplos mais divulgados são os fluxos de Argoncilhe ( $\mathrm{St}^{\mathrm{a}}$ Maria da Feira) e de Ventosa (Vila Verde).

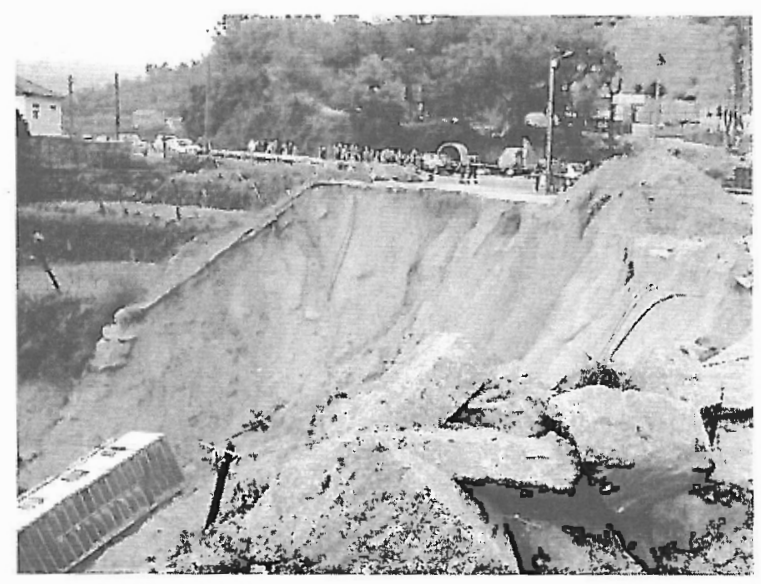

Foto 11 - Cicatriz do movimento de Ventosa (Vieira do Minho). A cicatriz desenvolve-se totalmente nos materiais do aterro.

No caso do fluxo de lama de Argoncilhe a rede hidrográfica apresenta um fraco encaixe e o perfil longitudinal tem um declive fraco a moderado, sempre inferior a $10^{\circ}$. Em toda a área as vertentes apresentam um perfil convexo sendo os declives máximos da ordem dos $11^{\circ}$. Ao longo da vertente, a alteração do gnaisse é importante o que resulta de fracturação directamente relacionada com a falha Porto/Tomar. Esta fracturação permitiu a existência de uma faixa de alteração ao longo da vertente com forte componente argilosa. É ao longo desta vertente e perpendicularmente a esta banda de intensa alteração que se encaixaram pequenos valeiros de perfil longitudinal de fraco declive. Estes pequenos encaixes apresentam um escoamento esporádico o que permitiu a difusão da ideia de se tratar de um curso de água seco.

Num destes valeiros foi instalado um aterro que servia de parque de viaturas pesadas de um armazém ${ }^{(11)}$. Este aterro não tinha qualquer estrutura de drenagem.

(11) Neste movimento foram destruídos cinco veículos pesados e respectiva carga, parte significativa do armazém, uma propriedade agrícola, vários há de floresta e foi afectada uma estrada. 


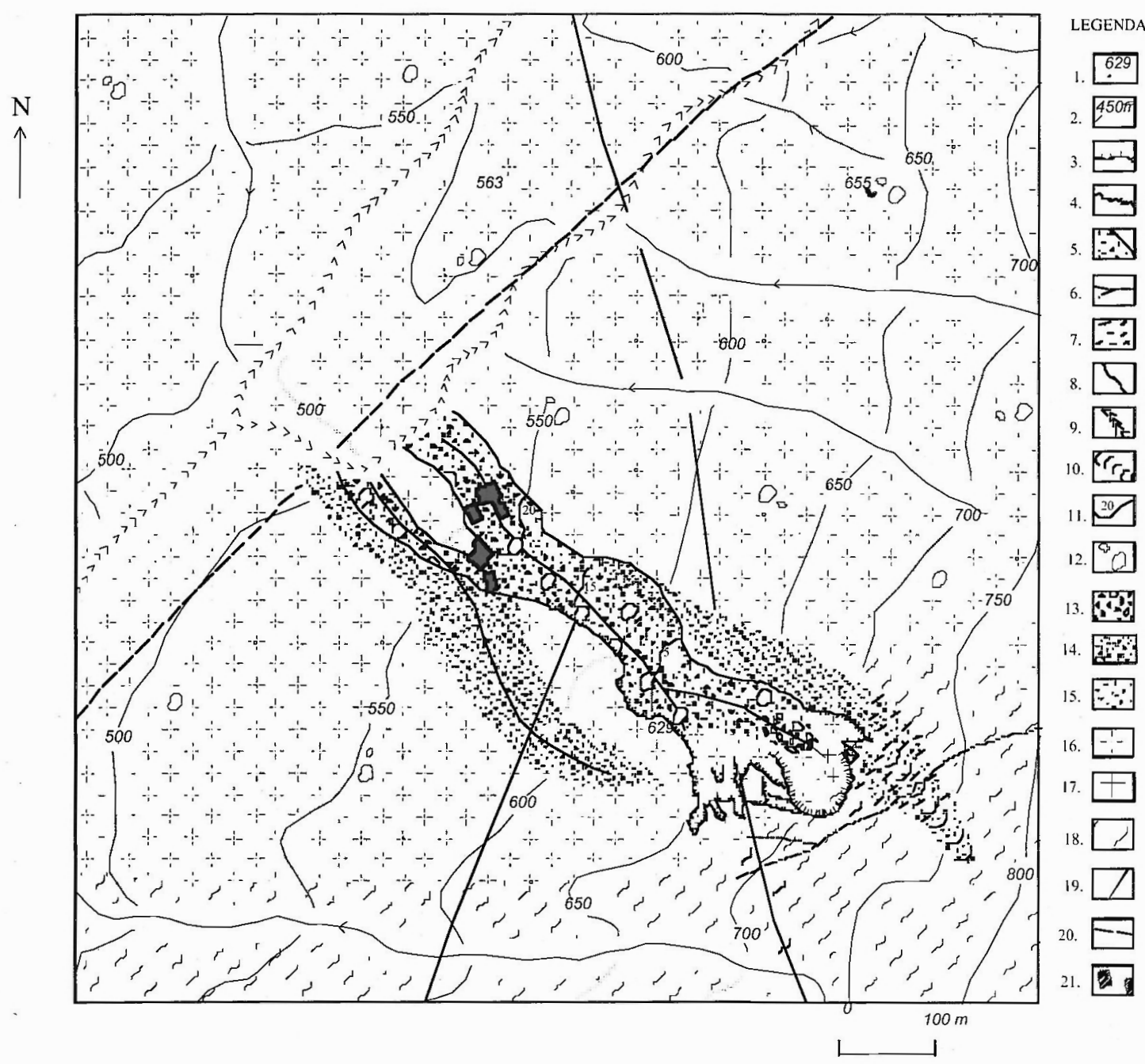

Fig. 4 - Esboço geomorfológico ce Covelo do Gerês. 1. Ponto cotado, 2. Curva de nível, 3. Cicatriz do fluxo de detritos, com mais de $50 \mathrm{~m}$, 4. Idem, com mais de $20 \mathrm{~m}, 5$. Limite da área de acumulação, 6. Fendas profundas, 7. Área com fendas superficiais, 8. Barranco, 9. Vale em forma de V, 10. Vale em forma de berço, 11. Rebordo de acumulação, com altura de $20 \mathrm{~m}$, 12. Bolas graníticas, 13. Escombreira de gravidade.

14. Detritos movimentados pelo fluxo, 15. Depósito de vertente argiloso, 16. Granito do Gerês, muito alterado, 17. Granito do Gerês. 18. Metasedimentos, 19. Falha, 20. Falha provável, 21. Casas.

Toda a secção do encaixe foi colmatada pelo aterro constituído por material essencialmente argiloso. O fluxo de lama destruiu o aterro, parte do armazém e ainda fez recuar a cicatriz em vários metros para montante. Apesar do declive fraco a moderadamente fraco, desenvolveu-se um processo que implicou a movimentação de várias toneladas de material de aterro. Nestaárea, existem vestígios de movimentações semelhantes que se traduzem na disposição das cabeceiras de alguns barrancos em forma côncava a que corresponde, na base da vertente, um depósito em forma de leque coluvial. A semelhança entre o movimento de Argoncilhe e estas formas de encaixe ao longo da mesma vertente sugere a existência de outros movimentos, já bastante evoluídos, com a mesma origem.

Uma primeira leitura da dinâmica geomorfológica desta área poderá conduzir à ideia de fraca susceptibilidade geomorfológica a movimentos de vertente. Porém, uma intervenção humana que colmata um valeiro, de escoamento esporádico, com materiais de aterro, poderá alterar drasticamente as condições geográficas de ocorrência de movimentos de vertente. Neste caso, a acção humana é um factor de agravamento da susceptibilidade geomorfológica a movimentos de vertente. A rapidez com que se procede à alteração das condições da dinâmica do meio físico permite uma alteração importante da cartografia dos riscos 
naturais tornando áreas de fraca susceptibilidade geomorfológica em áreas de forte a muito forte susceptibilidade geomorfológica. .

Em Vieira do Minho, no lugar de Ventosa ocorreu um movimento de vertente resultante da movimentação de um aterro (fot. 10). Os materiais deslocados são exclusivamente do aterro construído junto à estrada. Desse aterro resultou a destruição de uma máquina de mobilização de materiais, duas pontes, um contentor e a morte de uma pessoa. $O$ aterro é de grandes dimensões e colmata por completo um valeiro. Estando localizado a jusante da estrada, provavelmente terá obstruído o dreno da linha de água que usualmente é colocado para drenagem do escoamento superficial.

Os materiais que constituem o aterro são muito heterogéneos oriundos de outros locais. A sua heterometria é muito grande e estavam dispostos, aparentemente, sem qualquer tipo de compactação. No rebordo, a jusante, apresentava um conjunto de blocos sobrepostos que tinha por objectivo suster os materiais mais finos. Embora o aterro seja constituído, no essencial, por materiais de textura arenosa, apresenta muitos elementos grosseiros, nomeadamente blocos, cujo diâmetro maior frequentemente ultrapassa o metro.

Uma das características mais importantes deste movimento refere-se ao tipo de material afectado. A superfície de rotura desenvolve-se exclusivamente nos materiais do aterro que constituem a totalidade da massa movimentada. Este facto deve-se à saturação do aterro à saída do dreno que canaliza a linha de água sob a estrada. O aterro constitui um obstáculo à rápida drenagem propiciada pelo dreno sob a estrada. A saturação era inevitável e a pressão dos materiais sobrepostos à área saturada permitiu a rotura e o desenvolvimento do movimento. $\mathrm{O}$ forte declive da vertente onde está encaixado o valeiro, de perfil longitudinal também declivoso, promoveu a aceleração do movimentoe a mobilização de elementos grosseiros, em cerca de $5 \mathrm{Km}$.

\section{Os mantos de alteração espessos}

A grande maioria dos movimentos de vertente que ocorrem a expensas de mantos de alteração desenvolvidos a partir de granitóides são peliculares. Os fluxos de detritos aparecem como os mais vulgares e apresentam uma forte dinâmica, com grande velocidade e forte poder erosivo. Poucos têm sido os registos de movimentos mais profundos. Há, contudo, dois exemplos característicos de movimentos de vertente de maior profundidade: em Cestães (Arcos de Valdevez) e Covelo do Gerês (C. BATEIRA e L. SOARES, 1997).

Ambos os movimentos têm características de movimentos complexos e deslocam uma grande massa

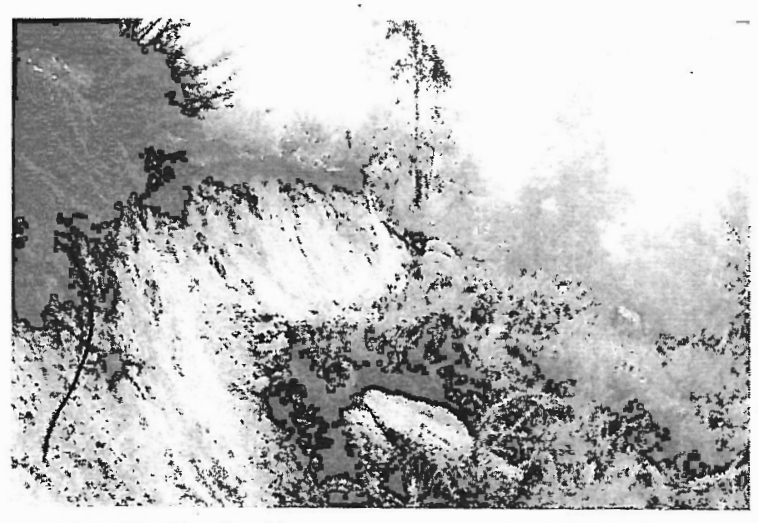

Foto 12 - Cestães. Fendas na parte superior do movimento complexo, esboço de provável cicatriz principal, considerando evolução a longo prazo.

de manto de alteração. As cicatrizes são múltiplas e apresentam uma grande profundidade. No conjunto têm uma extensão superior a 50 metros, tanto em largura como em altura. O movimento do Covelo do Gerês desenvolveu-se durante vários dias, tendo apresentado alguns movimentos precursores, o que permitiu a reacção da população local, registando-se unicamente perdas materiais (fig. 4).

No caso do movimento de Cestães tudo indica que se trata de uma fase inicial da movimentação (fots. 12). A frente da massa movimentada foi objecto de uma intervenção (alargamento de um caminho) que provocou o desabamento da frente do movimento e a perda de apoio do restante material, provocando a abertura de fendas a montante. Dir-se-ia que estamos perante movimentos complexos e semelhantes, mas em fases diversas de desenvolvimento. Se as condições hidro-meteorológicas se tivessem mantido em Cestães, poderia ter-se assistido à continuação do movimento, com consequências materiais mais importantes.

O material movimentado é, no essencial, manto de alteração granítico, constituído a expensas dos granitos do Extremo e do Gerês. A fracturação é extremamente profunda e intensa o que representa um factor importante no processo de alteração química dos granitóides (L. SOARES, 1992). Esse facto permitiu a formação de mantos de alteração espessos, profundamente encaixados por vales de fractura, com vertentes de declives fortes (quase sempre superiores a $30^{\circ}$ ).

As condições hidrológicas em que ocorreram ambos os movimentos são radicalmente diferentes das que se verificam nos fluxos de detritos. A espessura dos mantos de alteração comanda as condições da conductividade hidráulica e determina o tipo de movimentos. Nos fluxos de detritos a pequena espessura do manto de alteração conduz à rápida saturação da superfície da frente de alteração que se encontra a 
pouca profundidade. A pouca espessura permite a saturação e ofluxo desencadeia-se. É um movimento rápido e inesperado (C. BATEIRA e L. SOARES, 1995). No caso da alteração ser profunda, a saturação faz-se progressivamente de baixo para cima, porsubida donível freático. A conductividade hidráulica do manto de alteração é forte e, portanto, é difícil atingir-se o ponto de saturação. Só uma subida pronunciada do nível freático permite atingir a saturação da parte inferior do manto de alteração criando condições para a instabilidade da vertente. Basta, para tal, que haja uma intervenção reduzindo o suporte de apoio, para que o movimento se inicie.

Neste processo de saturaçâo do manto de alteração por subida do nível freático desempenha um papel essencial a profundidade da alteração e a espessura do manto de alteração. A infiltração fácil e a forte conductividade hidráulica, características de mantos de alteração de textura grosseira, conduziu à subida donível freático, na sequência de prolongados períodos de precipitação, que culminaram com um episódio chuvoso de forte intensidade (a estação meteorológica do Extremo registou, no dia 7 de Dezembro de 2000, $170 \mathrm{~mm}$ ). Este facto, explica porque motivo este tipo de movimento não ocorre ao longo de linhas de água. Se os fluxos de detritos se localizam nas linhas de água de primeira ordem, fruto de fracas espessuras de mantos de alteraçãoe da convergência de drenagem, as subidas do nível freático responsáveis pelos movimentos de vertente complexos ocorrem em vertentes convexas ou rectilíneas, desde que haja grande densidade de fracturação. Aí, o desgaste dos mantos de alteração é menor, o que permite a conservação de espessuras maiores, cuja estabilidade só é ameaçada por perda de suporte resultante de acção erosiva ou por intervenção antrópica.

Para a definição das áreas de maior susceptibilidade geomorfológica a movimentos de vertente complexos, em afloramentos de granitóides, parece ser essencial

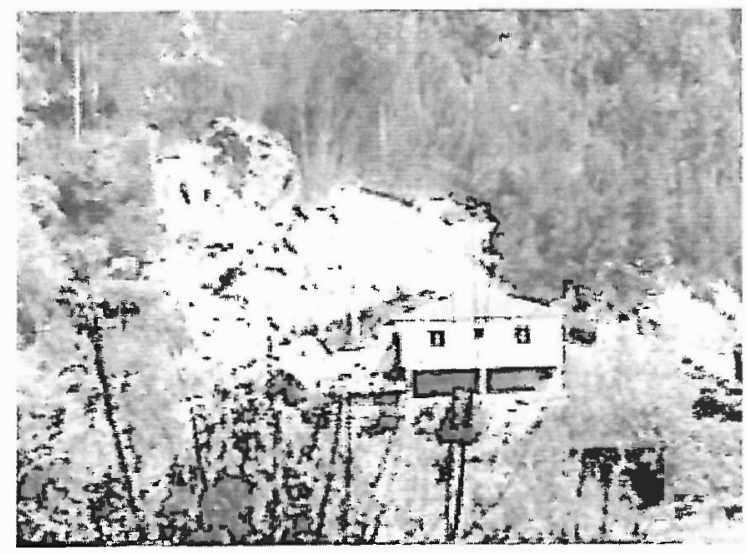

Foto 13 - Cestães (Arcos de Valdevez). Desabamento na frente do movimento de vertente.

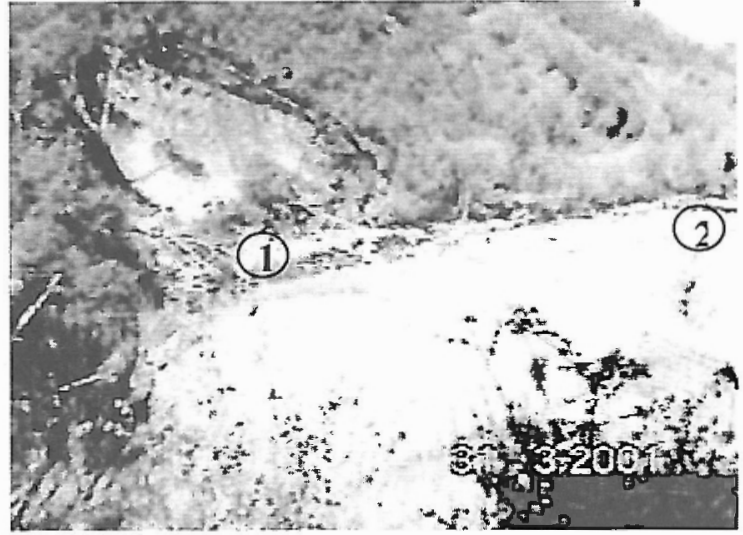

Foto 14 - Chã (Cinfães, rio Bestança, margem sul do rio Douro).

1. Parte da acumulação resultante do deslizamento que constituiu a barragem natural. 2. Parte da área erodida pela destruição da barragem natural.

a cartografia dos mantos de alteração de grande espessura. Para isso desempenham um papel determinante as condições hidro-geomorfológicas responsáveis pela ocorrência deste tipo de movimentos. Isto explica, também, a razão porque ocorrem em áreas de divergência de drenagem, superficial ou interna. Por este motivo torna-se essencial o registo e cartografia dos diversos tipos de mantos de alteração e a sua espessura. Também aqui, a fracturação tem desempenhado um papel importante e a identificação dos vales de fractura, com vertentes de forte declive e alteração profunda, parece ser um factor importante para a cartografia dos riscos naturais.

Sabemos da grande estabilidade dos mantos de alteração granítica. Isso explica a muito pouca frequência de ocorrência de movimentos complexos. Porém, essa estabilidade pode ser posta em causa pela acção humana, o que constitui, a par da precipitação, um dos factores mais imprevisíveis.

No movimento de Covelo do Gerês, ocorrido entre 10 e 22 de Dezembro de 1966, não temos indicações certas sobre provável intervenção humana que criasse condições para o início do movimento ${ }^{(12)}$. Contudo, em Cestães, o desencadear do movimentoestá indirectamente ligado ao alargamento de um caminho rural, que criou as condições de instabilidade reveladas, mais tarde, durante o inverno chuvoso de 2000/2001.

\section{Vertentes regularizadas por depósito e trabalho de sapa}

Oforte encaixe da rede hidrográfica que se verifica nas montanhas do NW Português permitiu o desenvolvimento de depósitos que regularizam as vertentes.

(12) Algumas informações recolhidas no terreno indicam a coincidência do movimento com algumas explosões relacionadas com a construção de um túnel. 
Esses depósitos apresentam características diversificadas. Por vezes, são de textura muito grosseira e sem matriz, outras vezes constituídos por argilas de espessuras variáveis alternando com camadas de gelifractos (com provável origemem processos periglaciares). Nas áreas de afloramentos de granitóides apresentam características solifluxivas, com calhaus dispersos, envoltos em matriz fina.

Estes depósitos são, frequentemente, sujeitos a um importante trabalho de sapa dos cursos de água junto da base da vertente. O trabalho de erosão provoca o deslizamento ou até o desabamento dos materiais do depósito criando uma barragem natural temporária.

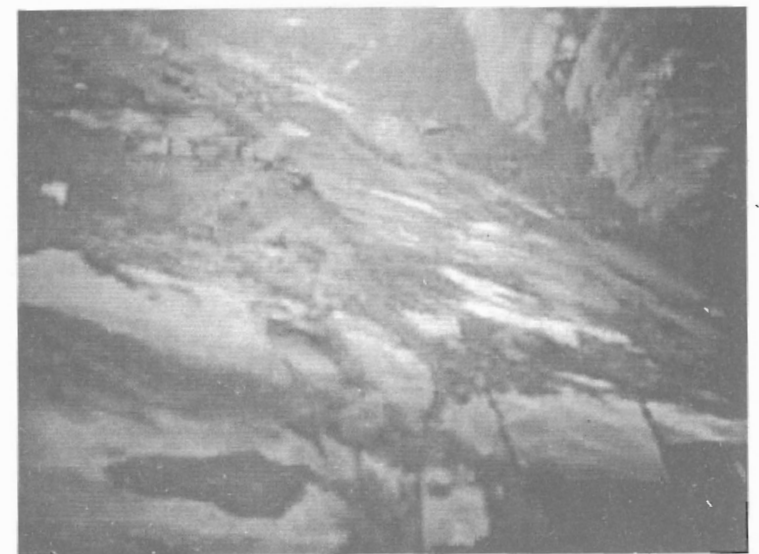

Foto 15 - Margem $S$ do rio Douro (estrada nacional $n^{\circ} 222$, entre a Régua e Armamar). Note-se a inclinação, para N, dos planos de xistosidade. Vista parcial do plano de deslizamento de um pequeno movimento de vertente.
Quando a barragem entra em rotura, desenvolve processos de erosão e transporte fluvial, que, muitas vezes, ultrapassam as margens do leito menor.

Há notícias de vários processos deste tipo ${ }^{(13)}$. A fot. 14 documenta um deslizamento ocorrido no vale de fractura do Bestança (afluente da margem esquerda do rio Douro, Cinfães). Na sequência do deslizamento provocado pelo trabalho de sapa do curso de água constituiu-se uma barragem natural. Ao fim de 30 dias os materiais depositados na base da vertente cederam e provocaram uma onda de cheia que destruiu campos agrícolas que ocupavam a margem.

Embora o risco associado a esta dinâmica fluvial não esteja directamente relacionado com movimentos de vertente, o factor desencadeante é um deslizamento ocorrido num depósito de vertente que a regulariza. Este processo, em conjunto com os anteriormente descritos, indica-nos que estamos perante uma nova necessidade, a cartografia de todas as formações superficiais. A elaboração desta cartografia, é instrumento de trabalho determinante na construção da cartografia da susceptibilidade geomorfológica e do risco natural, por dois motivos:

$1^{\circ}$ Permite o registo dos depósitos que resultam de outros movimentos de vertente, identificando áreas prováveis de mais elevadas susceptibilidade geomorfológica.

(13) Temos notícia de que na serra do Soajo, na localidade de Roussas. ocorreu umprocesso semelhante que resultou noderrame de uma grande quantidade de sedimentos (predominantemente areias e calhaus) na parte nova da aldeia.
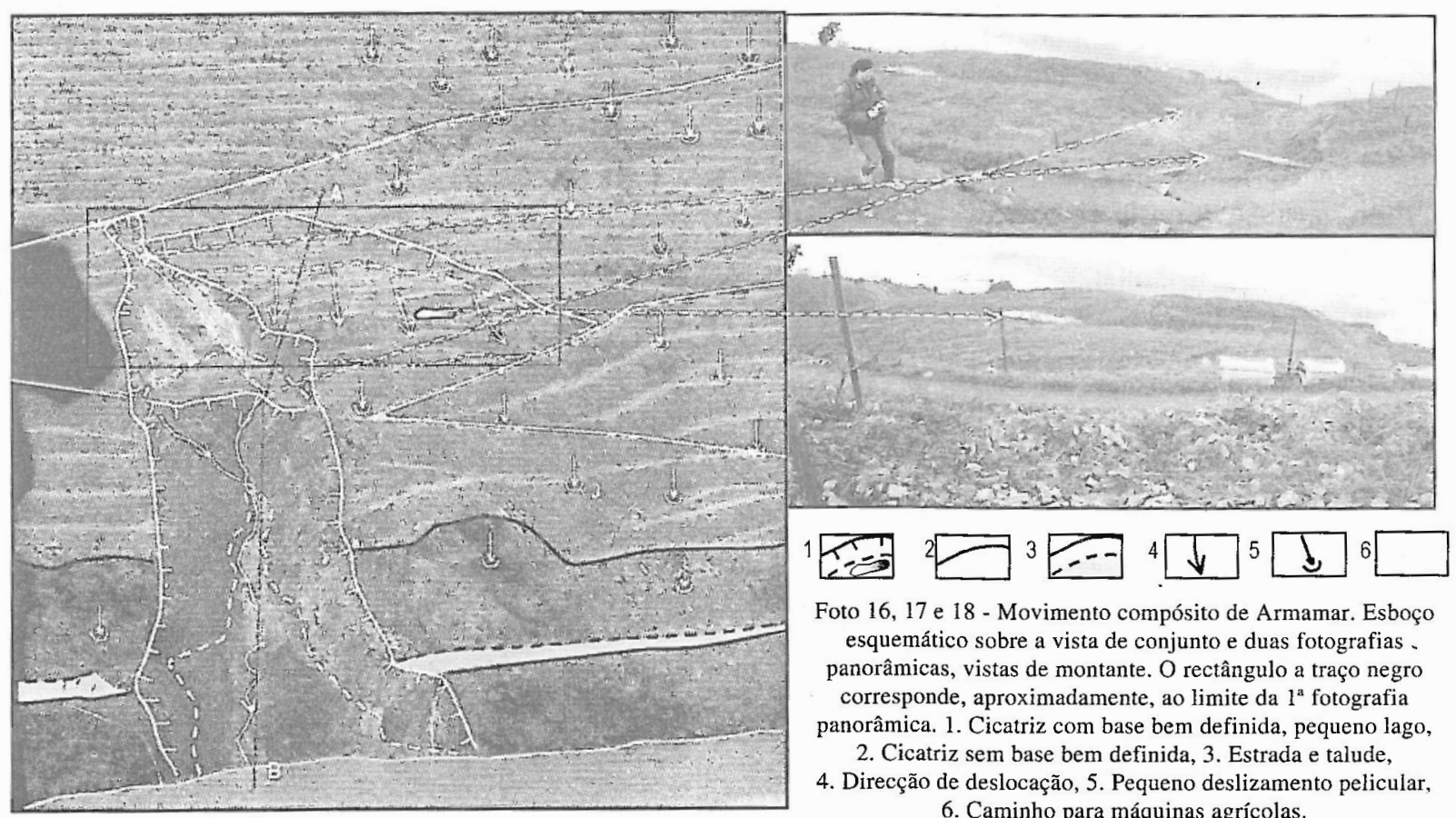

Foto 16, 17 e 18 - Movimento compósito de Armamar. Esboço esquemático sobre a vista de conjunto e duas fotografias . panorânicas, vistas de montante. O rectângulo a traço negro corresponde, aproximadamente, ao limite da $l^{\mathrm{A}}$ fotografia panorâmica. 1. Cicatriz com base bem definida, pequeno lago, 2. Cicatriz sem base bem definida, 3. Estrada e talude, 4. Direcção de deslocação, 5. Peq̧ueno deslizamento pelicular, 6. Caminho para máquinas agrícolas. 
$2^{\circ}$ As formações superficiais que regularizam as vertentes estão sujeitas a trabalho de sapa e, em si, são importante factor de risco natural.

\section{Planos de xistosidade conformes à vertente}

O movimento de Armamar ocorreu na margem $S$ do rio Douro no dia 2 de Janeiro de 2003, e afectou a estrada ${ }^{\circ} 222$, entre Régua e Armamar. Desenvolveuse a expensas da Formação do Pinhão. No local do movimento esta formação apresenta a sobreposição de metaquartzograuvaques por uma espessa bancada de filitos cloríticos. Na margem $S$ os metasedimentos inclinam para $\mathrm{N}$ (fot. 15) ao passo que na margem $\mathrm{N}$ o fazem para S. Em ambas as situações são, portanto, conformes às respectivas vertentes. Este sector do rio Douro está encaixado numa falha de direcção $\mathrm{E}-\mathrm{W}$, tal como é sugerido pelos diferentes pendores das camadas em ambas as margens e pelas facetas triangulares talhadas nas vertentes pelo encaixe do rio Douro e seus afluentes. Por outro, a observação cuidada de alguns taludes artificiais (nos metaquartzograuvaques) permite verificar, em pequenos sectores, a existência de estrias características de espelhos de falha.

Este factoexplica a grande facilidade de desenvolvimento de movimentos de vertentes. Tanto o deslizamento como os desabamentos de blocos são muito frequentes neste tramo do vale do Douro. Em geral, os planos de deslizamento coincidem com os planos de xistosidade.

Na vertente da margem $\mathrm{N}$, na parte superior da vertente, ao longo de um caminho rural, observamse vários deslizamentos de blocos ocorridos nos metaquartzograuvaques. Na margem $\mathrm{S}$, a abertura da estrada $n^{\circ} 222$ foi feita na base da vertente e apresenta um conjunto de taludes de maiores dimensões, o que permite uma maior instabilidade de vertente. Os movimentos são mais numerosos e de maior dimensão sendo que coincidem com linhas de água de encaixe incipiente (barrancos).

De uma forma geral, podemos dizer que a formação do Pinhão é pouco permeável e, nas vertentes do vale do Douro, com declives muito fortes, o escoamento superficial é dominante. A circulação hídrica subsuperficial faz-se com recurso às fracturas, planos de xistosidade, contactos entre formações litológicas ou superficiais. Desta forma, as superfícies de saturação desenvolvem-se ao longo das descontinuidades litológicas que, quando apresentam pendor em conformidade com a disposição morfológica da vertente permitem o desenvolvimento de movimentos de vertente.

Na vertente $S$ do vale do Douro foram construídos pequenos patamares para plantio da vinha, separados por taludes sem qualquer estrutura de sustentação. Estes patamares situam-se na formação detrítica e ocupam a parte superior da vertente, de declive menor. Em simultâneo, foi aberto um caminho rural, para utilização de máquinas agrícolas, ao longo de toda a extensão da vertente. Neste caminho foi introduzido um sistema de drenagem, parcialmente enterrado. Foi a rotura de um desses canais, provocada pela deslocação inicial dos materiais da vertente, que provocou a ocorrência de um fluxo de detritos. O impacto causado na estrada nacional foi de tal monta que provocou a sua destruição. O facto de se ter feito uma intervenção capaz de criar aclives foi o suficiente para aumentar a capacidade de infiltração, e promover a saturação da superfície de contacto entre as diversas formações litológicas.

\section{Escoamento interno em patamares agrícolas}

Ainda na região da Régua, em Alvações do Corgo, ocorreu um fluxo de lama que, pelas suas consequências, foi amplamente divulgado pelos meios de comunicação $\operatorname{social}^{(14)}$ (fot. 19 e 20). A constituição litológica da

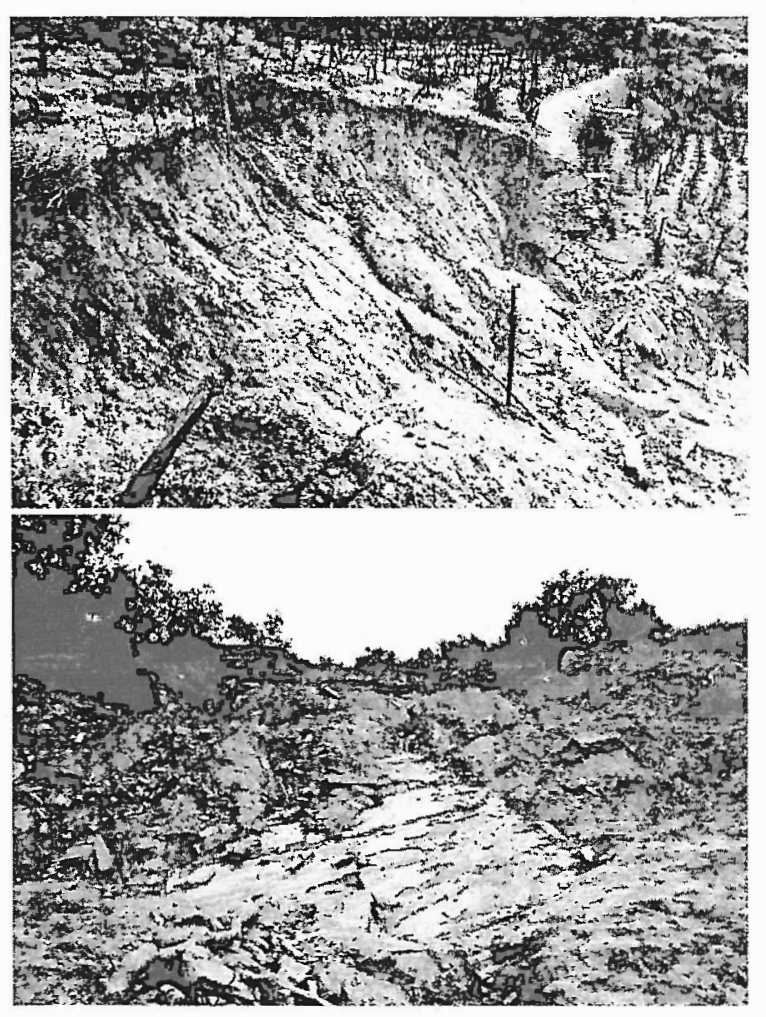

Fotos 19 e 20 - Alvações do Corgo. Importância dos planos de estratificação que coincidem com a superfície de deslizamento.

(14) O movimento desenvolveu-se em patamares agrícolas para plantio da vinha, destruiu uma casa e matou três pessoas. 
vertente está directamente relacionada com o complexo xisto-grauváquico do pré-câmbrico. Na vertente em causa existe uma cobertura detrítica de forte componente argilosa, de espessura, aproximada, de dois metros, onde foram construídos patamares agrícolas com uma inclinação suave, para o plantio da vinha. Sob a cobertura detrítica dispõe-se o complexo xisto grauváquico, que, no local, é constituído por xisto, cujos planos de xistosidade têm pendor conforme à vertente (fot. 19 e 20 ).

A importância do estudo deste movimento está relacionado com as condições hidrológicas do escoamento superficial e subsuperficial que resultam do arranjo das vertentes para a produção agrícola. Com efeito, nos dias imediatamente a seguir ao movimento verificava-se a saturação total dos materiais detrítos onde se processou o movimentoe oescoamento interno transformava-se em escoamento superficial junto da base dos muros de sustentação dos patamares. Quase sempre esse processo ocorria em áreas onde os referidos muros estavam assentes directamente sobre o xisto. Porém, no local do movimento, o muro de suporte estava assente sobre os materiais detríticos. Quase sempre, o processo de drenagem da formação detrítica faz-se junto à base do muro. A água que escoa à superfície infiltra-se imediatamente a montante do muro, adicionando-se ao escoamento interno junto à base.

O cultivo da vinha faz-se utilizando algumas técnicas tradicionais de drenagem, extremamente eficazes na manutenção da estabilidade dos terrenos. Em geral, escavam-se pequenos sulcos com uma disposição próxima da das curvas de nível, evitando que o escoamento superficial se concentre ou atinja os muros de suporte. Em simultâneo retira-se todo o coberto herbáceo, fomentando oescoamento superficial de forma a que o processo de infiltração seja reduzido ao mínimo. Esta água é canalizada para sulcos, por vezes construídos em pedra, que orientam todo o escoamento superficial para uma linha de água permanente. No caso do movimento de Alvações do Corgo a propriedade agrícola onde ocorreu não tinha sido devidamente drenada e os pequenos regos paralelos às curvas de nível não foram construídos.

Apesar de não ser um movimento de grandes dimensões, justifica-se o seu estudo pelo conjunto de informações que dá sobre as práticas agrícolas tradicionais e mostra a sua importância no estudo das condições de estabilidade das vertentes. Este movimento, em conjunto com o de Armamar, sugere que é extremamente importante o estudo das condições de utilização dos solos, as técnicas tradicionais de arranjo das vertentes e interroga-nos sobre o conjunto de intervenções que estão a ser realizadas nas vertentes da área demarcada no vinho do Douro, no âmbito da modernização das explorações agrícolas.

\section{Manutenção das estruturas tradicionais de drena- gem das vertentes}

O movimento múltiplo de Ariz (Régua) não parece ligado a nenhum elemento estrutural, mas sim às condições de escoamento (fig. 5). Este movimento ocorreu em 26 de Janeiro de 2001, provocou a destruição de duas habitações e de um veículo automóvel, tornou intransitável uma estrada por um breve período de tempo, destruiu um caminho e patamares de vinha e originou uma vítima mortal.

O movimento desenvolve-se a expensas de uma cobertura detrítica, essencialmente argilosa, que se sobrepõe aos xistos luzentes pertencentes ao complexo xisto-grauváquico do pré-câmbrico. A espessura visível desta cobertura éde 3 metros. A vertente estáorganizada em patamares agrícolas que são suporte ao plantio da vinha. Dado o carácter argiloso da formação detrítica construíram-se muros de suporte que, junto à cicatriz, têm cerca de 3 metros de altura.

A vertente onde ocorreu o movimento é uma vertente complexa, sendo convexa na parte superior e apresenta várias roturas de declive, promovendo, para jusante, um aumento do declive. A montante os declives variam entre os $20^{\circ}$ e os $25^{\circ}$ e a secção média da vertente aproxima-se dos $45^{\circ}$, diminuindo novamente na base da vertente, junto ao rio Douro. É a jusante de uma rotura de declive que se localiza o movimento. Neste local são visíveis as estruturas construídas de pequenos canais, dispostos ao longo das linhas de água de escoamento esporádico. Para estes canais convergem pequenos sulcos de drenagem dos patamares agrícolas, periodicamente reavivados pelos proprietários. Estas estruturas elementares de drenagem são essenciais para a diminuição da capacidade de infiltração dos patamares. Há, no entanto, sinais de degradação destas estruturas.

Quanto ao tipo de actividade, pode ser classificado como um movimento sucessivo, já que é constituído por dois fluxos de lama que ocorreram com um intervalo de tempo reduzido ${ }^{(15)}$. O primeiro formou uma cicatriz de $10 \mathrm{~m}$ de largura, $15 \mathrm{~m}$ de comprimento e cerca de 3 m de altura (fot. 21). Osegundo movimento, situado a SW converge para a parte terminal da cicatriz do primeiro, galgando um muro de suporte de um patamar agrícola (fot. 22). O facto deste muro estar conservado, evidencia que o segundo movimento não resultou da perda de apoio provocada pela ocorrência do primeiro movimento. São portanto, dois movimentos independentes, tanto nos materiais afectados, como no momento em que ocorreram. Não há partilha de materiais nem de superfície de rotura. Inicialmente movimentam-se exclusivamente

(15) Durante os trabalhos de resgate da vitima mortal ocorreu o segundo movimento. 


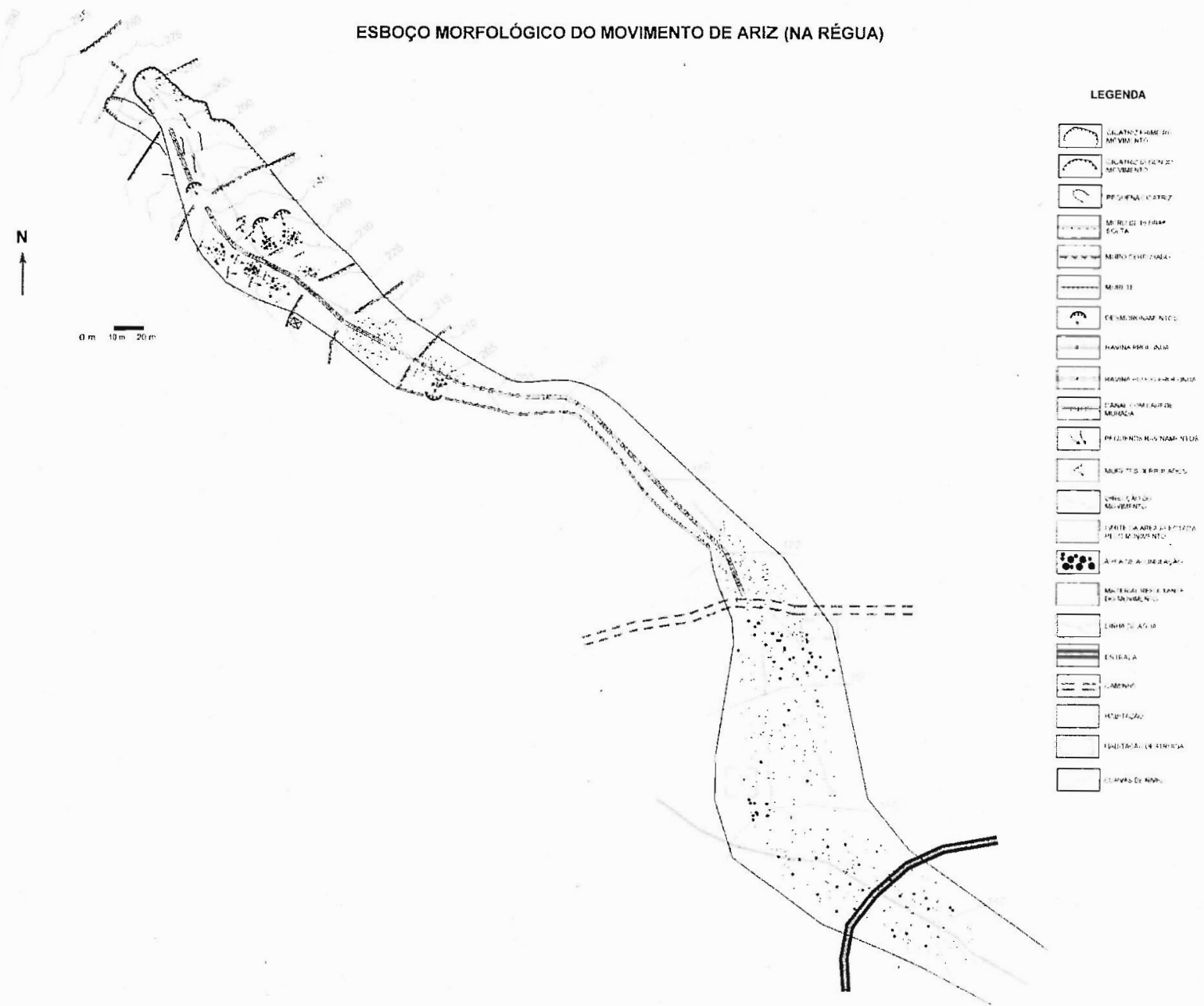

Fig. 5: Esboço geomorfológico do movimento múltiplo de Ariz (Régua). O movimento ocorre imediatamente a jusante de uma rotura de declive com aumento do declive para jusante. Trabalho de campo efectuado em conjunto com L. Pinto e J. Gomes no âmbito da licenciatura de Geografia da Fac. de Letras do Porto. A figura é adaptada do mesmo trabalho.

materiais finos, conferindo-lhes as características de fluxos de lama. Quando atingem algumas das estruturas de suporte dos patamares agrícolas mobilizam-se materiais de maiores dimensões, adquirindo as características de fluxo de detritos.

Num primeiro momento, o movimento desenvolvese ao longo da linha de água (declives entre os $40^{\circ} \mathrm{e}$ os $45^{\circ}$ ) mobilizando uma quantidade crescente de materiais. Próximo do caminho, que destruiu, alarga a sua área de transporte para além do pequeno barranco onde atingiu duas casas, depositando os materiais mais grosseiros que tinha mobilizado dos muros destruídos. Ao atingir a estrada, dispersa os materiais argilosos ao longo dos patamares agrícolas que se situam a jusante. As áreas de erosão são constituídas, no essencial, pelas cicatrizes e, ainda, reduzidos sectores do barranco que funcionou como área de transporte. A deposição fez-se no sector das casas destruídas onde o declive é consideravelmente menor $\left(14^{\circ}\right.$ a $\left.16^{\circ}\right)$. O segundo movimento desencadeou-se horas mais tarde (já se desenvolviam trabalhos de resgate da vítima mortal), mobilizou uma quantidade menor de materiais e convergiu para a área afectada pelo primeiro fluxo. Contudo, não atingiu as dimensões do anterior. Posteriormente aos movimentos ocorreram pequenos desmoronamentos nos patamares agrícolas situados ao longo e nos limites laterais da área afectada, a montante das habitações destruídas.

O movimento de Ariz constitui um exemplo de movimento em vertente complexa, onde a variação de declives e respectiva rotura, conducente a um aumento de declive a jusante, comanda o fluxo interno e determina a saturação de alguns sectores da vertente. À semelhança do que ocorre em Cavez, a existência 


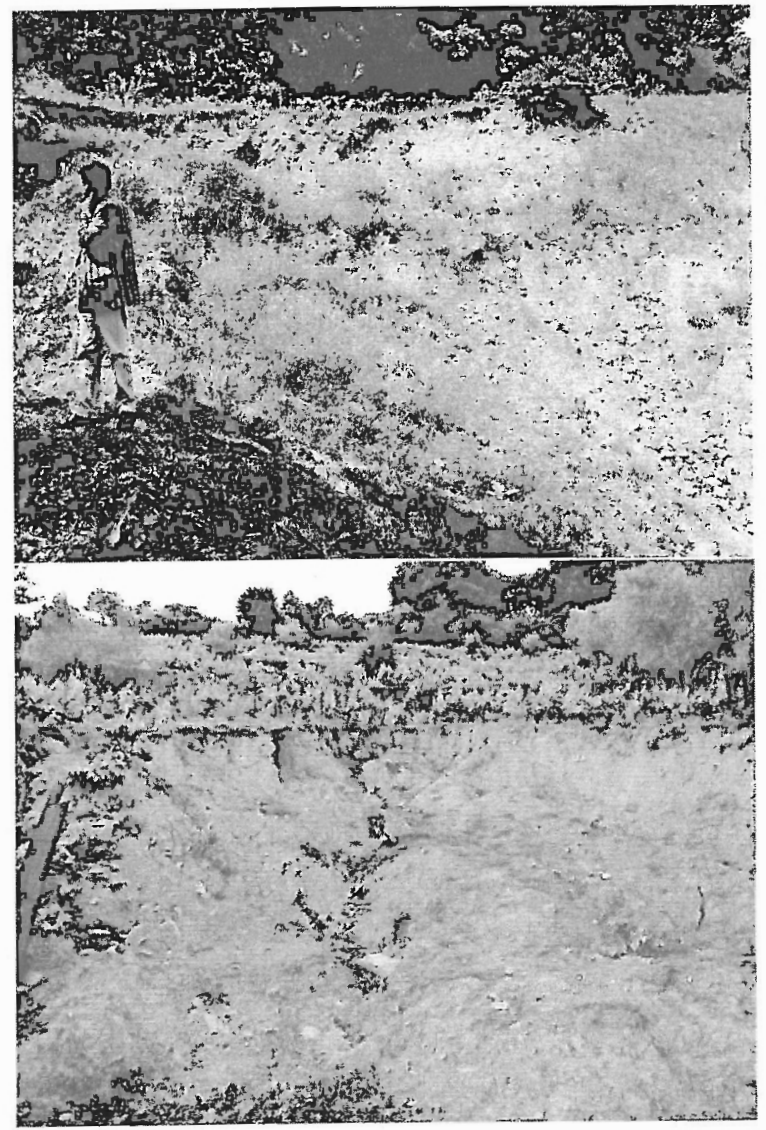

Fotos 21 e 22 - Movimento de vertente de características múltiplas em Ariz (Régua). Em cima, cicatriz do primeiro fluxo. Em baixo, cicatriz do $2^{\circ}$ fluxo.

de um sector da vertente, a montante, e de menor declive, permite uma maior infiltração em detrimento do processo de escoamento superficial. Contudo, esse fluxo interno converge para as áreas de encaixe da rede hidrográfica. Essa convergência origina a saturação desses materiais, sobretudo junto das roturas de declive. Nestes sítios, o escoamento interno tem a tendência em transformar-se em fluxo superficial, o que torna os materiais próximo da superfície mais saturados. Sendo o declive maior, há menor base de sustentação permitindo a criação de condições de ocorrência de movimentos de vertente.

Neste caso, à semelhança do que ocorreu em Cavez, o factor morfológico relacionado com a forma da vertente parece ser determinante na localização do movimento de vertente, a par com o arranjo em patamares agrícolas.

\section{Problemas da cartografia directa}

Como já foi referido, os elementos relacionados com a morfologia dos movimentos de vertente têm tendência a ser apagados no terreno. Quando os materiais onde se desenvolvem são friáveis, os processos erosivos posteriores vão progressivamente apagando os pormenores morfológicos das cicatrizes e mesmo das áreas de acumulação. Por vezes, só resta parte dos depósitos que deles resultam e algumas formas gerais no traçado das vertentes. Esse processo é tão mais rápido quanto mais importante é a actividade económica que utiliza esses terrenos. Nalguns desses movimentos já nãoé possível fazer qualquer identificação. Tanto em St. ${ }^{a}$ Marinha do Zêzere como em Cavez já não é possível qualquer observação da cicatriz.

Quando a cartografia da susceptibilidade geomorfológica se faz directamente sobre o terreno recorrendo ao registo da dinâmica e dos vestígios de movimentos de vertente é necessário que a experiência de quem faz o levantamento e registo seja alicerçada em bons conhecimentos teóricos e numa vasta experiência em observação de movimentos de vertente conhecidos, tanto passados como actuais. Isso permitirá fazer a destrinça, entre as diversas formas do relevo, do que é indício de novos movimentos e vestígio de anteriores movimentos.

A observação do conjunto de movimentos de vertente referidos demonstra que pode existir um conjunto de áreas, muito semelhantes do ponto de vista hidro-geomorfológico, mas que não registaram qualquer indício de instabilidade. Este facto está relacionado com a distribuição espacial dos episódios chuvosos que originam os movimentos de vertente. Muitas vezes esses episódios são muito concentrados, tanto no tempo como no espaço (C. BATEIRA e L. SOARES, 1997)(16). Há, portanto, um conjunto de áreas, por vezes muito próximas, que apresentam as mesmas condições hidro-geomorfológicas e que experimentam comportamentos geodinâmicos muito diversos. Este facto impõe que o levantamento das condições de ocorrência de movimentos de vertente não se faça exclusivamente com recurso aos indícios e vestígios de movimentos de vertente, mas também ao registo dos factores permanentes responsáveis pelo seu desencadear, atribuindo uma grande importância ao papel da generalização na cartografia dos riscos naturais.

\section{A Cartografia indirecta}

\section{Os factores de ocorrência de movimentos de vertente e a generalização cartográfica}

A utilização dos métodos de cartografia indirecta pressupõe o cruzamento e sobreposição de diversas

(16) A pequena bacia hidrográfica do rio Cavalum (Penafiel) registou uma cheia rápida com várias destruições, embora nada tenha sido observado noutras bacias de igual dimensão que the estäo próximas. 
variáveis geográficas responsáveis pela ocorrência de movimentos de vertente. Esse procedimento é essencial para a definição da respectiva susceptibilidade geomorfológica. Dos vários procedimentos possíveis de utilizar em ambiente de Sistemas de Informação Geográfica, a sobreposição de níveis de informação, onde estejam cartografados os factores permanentes da ocorrência de movimentos de vertente, é o que mais se aproxima do método usado pela cartografia directa. Com efeito, para cruzar informação que é relevante para a definição da susceptibilidade geomorfológica é necessário um conhecimento dos diversos tipos de movimentos de vertente e dos factores responsáveis pela sua ocorrência.

No quadro 1 procurou-se sintetizar os factores que são responsáveis pela ocorrência do conjunto de movimentos de vertente apresentados nos pontos anteriores. A cartografia das áreas de maior susceptibilidade a movimentos de vertente exige o registo da informação relativa a esses factores. Por exemplo, a espessura dos mantos de alteração é o factor determinante na ocorrência de fluxos de detritos em afloramentos de granitóides. Como mero exemplo, pode dizer-se que a elaboração da cartografia relativa à susceptibilidade geomorfológica à ocorrência de fluxos de detritos necessita de execução de esboços das diversas espessuras das formações superficiais.

Da mesma forma, torna-se necessário proceder para com os restantes níveis de informação. As restantes formações superficiais como os depósitos de vertente, ou ainda as intervenções antrópicas, como os aterros e desaterros, a rede hidrográfica, os declives, a litologia, a tectónica, a morfologia, os processos erosivos..., são elementos que se torna indiśpensável introduzir ao nível dos sistemas de informação geográfica. A associação dos diversos elementos relacionados com os factores responsáveis pela ocorrência de movimentos de vertente poderão ser objecto de associação através do processo de análise topológica com recurso aos operadores lógicos boleanos (C. BATEIRA, 2001).

Contudo, os resultados dessa análise vai depender de dois factores essenciais: do rigor da informação recolhida sobre o terreno e da capacidade experiência do operador em ser fiel ao processo de recolha e produção da informação científica, ou seja, da experiência acumulada. Essa experiência revela-seessencial quando se organiza o conjunto de elementos que constituem as questões lógicas que definem as áreas de maior susceptibilidade. A elaboração das questões lógicas implica uma generalização da informação cujo rigor depende da experiência e do conhecimento que o operador tem sobre os processos de evolução de vertente da área em análise. Por exemplo, ao reconhecer que as linhas de água de primeira ordem são elemento determinante na ocorrência de fluxos de detritos teremos de seleccionar os elementos da rede hidrográfica de $1^{\text {a }}$ ordèm e relacioná-los com os restantes elementos naturais que propiciam os fluxos de detritos. Porém, os fluxos de detritos, quando ocorrem em bacias hidrográficas de $1^{\text {a }}$ ordem, rapidamente adquirem um traçado coincidente com o encaixe da rede
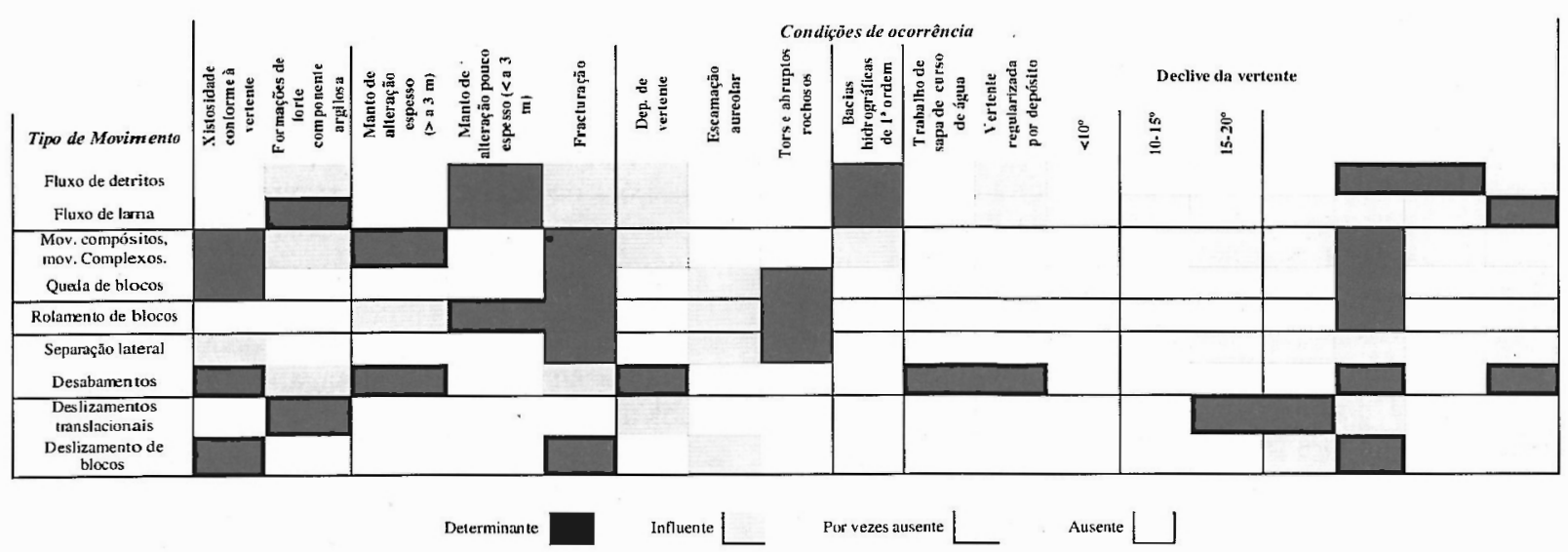

Quadro 1 - Quadro resumo dos factores naturais de ocorrência de movimentos de vertente, segundo o grau de influência. Este quadro pretende resumir o conjunto de factores registados nos movimentos de vertente observados e descritos no texto. É importante referir que este tipo de condições só se aplicam em áreas de maciço antigo do Norte de Portugal, onde predominam as rochas granitóides e metasedimentos.

Determinante - factor muito importante na movimentação dos materiais. Influente - desempenha papel importante, embora surja sempre associado a outros igualmente importantes. Por vezes ausente - factor importante na movimentações dos materiais, embora os movimentos de vertente possam ocorrer sem o seu contributo directo. Ausente - nos movimentos de vertente estudados não se verificaram influências significativas destes factores. 
hidrográfica, quase sempre, de ordem superior. Se as bacias de $1^{2}$ ordem constituem as áreas de desencadeamento deste processo, as linhas de água de ordem superior que se situam a jusante, constituem áreas afectadas e, por isso, devem ser consideradas áreas de forte susceptibilidade geomorfológica.

Estes exemplos permitem pôr em evidência que, mesmo quando se produz a cartografia da susceptibilidade em ambiente SIG, é necessário alicerçá-la numa recolha da informação sobre o terreno e na definição dos factores permanentes do risco geomorfológico com recurso ao estudo dos diversos casos conhecidos. O inverno de 2000/2001 com o cortejo de movimentos de vertente ocorridos em condições de ocorrência muito diversas, permitiu um avanço significativo na definição dos factores de risco natural relacionado com a evolução de vertentes. A investigação sobre as condições hidro-geomorfológicas de ocorrência de movimentos de vertente e a sua relação com os episódios chuvosos desencadeantes constitui o desafio próximo ao estado actual dos conhecimentos sobre a susceptibilidade geomorfológica a movimentos de vertente no Norte de Portugal.

Com o melhor conhecimento dos processos de escoamento interno e das condições de saturação das superfícies de rotura poderá proceder-se à generalização da cartografia de susceptibilidadecom maior fiabilidade, mesmo que não se verifiquem a existência de indícios ou vestígios de instabilidade de vertente.

\section{Os factores antrópicos: a imprevisibilidade}

A intervenção antrópica é um factor de risco natural extremamente importante uma vez que o tipo de intervenções operadas sobre o meio físico contribui para alteração muito significativa das condições de drenagem e saturação dos diversos materiais que constituem as vertentes. Com os exemplos apresentados é possível concluir que:

- num espaço de tempo muito curto podem ser alteradas as condições da dinâmica do meio físico;

- o poder de intervenção é fortemente acrescido pelo desenvolvimento tecnológico e o impacte das intervenções é cada vez maior. São cada vez mais as áreas problemáticas sujeitas a intervenções;

- uma área com forte potencial de estabilidade pode ser objecto de grande instabilidade em função da intervenção humana que possa ser executada;

- uma intervenção só pode ser equacionada com as respectivas medidas técnicas capazes de conservar o potencial de estabilidade da anterior intervenção;

- existem áreas onde a intervenção humana é de todo desaconselhada e devem ser desenvolvidas medidas de restrição ao uso dos solos que impliquem alterações profundas das condições da dinâmica do meio físico;

- nas áreas intervencionadas existe uma forte alteração da dinâmica hidrológica do meio físico pelo que os modelos de interpretação do processo de escoamento interno construídos para a análise de áreas não intervencionadas ficam desajustados, sendo necessário refazê-los. Por outro lado, os modelos utilizados pela mecânica dos solos não podem ser aplicados sem recurso à análise da influência dos diversos meios físicos sobre as forças que regem a estabilidade dos taludes. Quando um talude é aberto numa linha de água (mesmo de escoamento esporádico) não tem o mesmo comportamento geodinâmico daquele que é instalado numa vertente sem encaixe de qualquer género.

\section{Conclusão}

O conjunto de exemplos apresentados permite identificar várias das intervenções humanas desajustadas e que desenvolveram movimentos de vertente. Também aqui os processos desencadeados no inverno de 2000/2001 constituem elementos de estudo e deverão ser objecto de análise, sobretudo no sentido de se perceber em que medida foram alteradas as condições de drenagem e saturação dos materiais da vertente, dos que lhe foram acrescentados, bem como das consequências da construção de taludes artificiais. Realça-se o exemplo do movimento de Armamar como paradigma da alteração das condições hidrológicas numa vertente. Hoje, no vale do Douro desenvolve-se uma alteração profunda nas técnicas de cultivo da vinha cujas consequências sobre o escoamento, tanto interno como superficial, ainda estão por determinar. O movimento de Armamar dános indicação de que as consequências poderão ser graves e implicarão um aumento significativo do risco de movimento de vertente em áreas onde a probabilidade de ocorrência poderia ser menos forte.

Uma vez constatado que há um grau importante de generalização na elaboração dos mapas de riscos naturais, essa generalizaçãodeve basear-se em modelos de análise que considerem o conjunto de variáveis relacionadas com os movimentos de vertente. Não só os elementos geotécnicos, directamente relacionados com o comportamento geodinâmico dos materiais e as forças de tenção interna são relevantes nodesencadear dos processos. Também o enquadramento geográfico comanda as condições de saturação dos materiais. Nesse sentido, há que construir e introduzir modelos geográficos, com forte componente hidro-geomorfológica, na análise e interpretação das condições de 
circulação hídrica e de saturação responsável pela instabilidade das vertentes. São modelos que privilegiam a análise espacial na interpretação dos processos geomorfológicos de evolução de vertentes.

A cartografia dos riscos naturais deverá apoiarse neste tipo de modelos de forma a poder desenvolver a generalização credível, sobretudo em áreas onde não há indícios ou vestígios de movimentos de vertente. Este tipo de trabalho é fundamental na análise e produção da cartografia dos riscos naturais a grande e média escala.

\section{Referências bibliográficas:}

(2001) - "Processos erosivos no Norte de Portugal: definição das áreas de risco". Relatório do projecto de investigação científica. Departamento de Geografia da Fac. Letras da Univ. do Porto. Financiado pela FCT, policopiado.

COSTA, J. E. (1984) - "Physical geomorphology of Debris Flows", in Developments and applications of geomorphology, Ed por John E. Costa e P. Jay Fleisher, Springer-Verlag, New York, pp. 268-317.

COUDÉ-GAUSSEN, G. (1981) - Les Serras da Peneda et do Gerês. Étude Géomorphologique. Lisboa, Memórias do CEG, nº 5 , $255 \mathrm{p}$.

FERREIRA, A. de Brum e ZÊZERE, J. L.(1997) - "Geomorphological hazards in Europe, Portugal", in Developments in Earth Surface Processes, 5, ed. C. Enbleton e C. EmbletonHamann, Elsevier, Amsterdam, pp. 391-407.

PANIZZA, M. (1990) - "Geomorfologia applicata al rischio i all impatto ambientali. Um esempio nelle dolomiti (Italia)", Teruel, Actas da $1^{a}$ Reunión Nacional de Geomorfología, Vol.1, pp. 1-16.
PEDROSA, A. (1993) - Serra do Marão. Estudo de Geomorfologia. Policopiado. Dissertação de doutoramento, apresentada na Faculdade de Letras da Universidade do Porto. Porto, 478 ps.

PERRUSSET, A-C. (1976) - Glissements superficiels de terrains et rochers. Thèse présentée à l' Université de Nice pour obtenir le grade de Docteur D'État en Sciences, policopiado, 373 p.

REBELO,F.(1981)-"A acção humana como causa de desabamentos e deslizamentos.' Análise de um caso concreto". Biblos, Coimbra, LXXI, pp. 511-527.

REBELO, F. (1995) - "As catástrofes naturais e impacte ambiental. Os riscos. Reflexões sobre alguns casos estudados em Portugal". Actas do VI Colóquio lbérica de Geografia, vol. 2, 1992. Publicações da Universidade do Porto, Porto, pp. 962-965.

REBELO, F. (1999)_"“A teoria dorisco analisada sob uma perspectiva geográfica". Cadernos de Geografia, $n^{\circ} 18$. Fac. Letras da Univ. de Coimbra. Coimbra, pp. 3-13.

SANTOS, J. G. (2002) - "Cartografia automática do risco de movimentos de vertente; estudo aplicado à área de Peso da Régua, bacia do Douro - Norte de Portugal". Xeográfica, Revista de Xeografia, Território e Medio Ambiente, $\mathrm{n}^{\mathbf{0}} 2$. Santiago de Compostela, pp. 33-57.

SILVÉRIO, M. (2000)-Erosão hídrica dos solos. Tese de Mestrado, apresentada à Fac. Letras da Universidade do Porto, policopiado, $220 \mathrm{p}$.

SOARES, L. (1992)-As serras de Campelos e Maragotos. Contributo para um estudo de morfologia granítica. Dissertação de Mestrado apresentada à Universidade do Coimbra, Coimbra, 149 p. (policopiado).

ZÊZERE, J. L. (2002) - "Landslide susceptibility assessment considering landslide typology. A case study in area north of Lisbon (Portu-gal)". Natural Hazards and Earth System Sciences, $n^{\circ}$ 2. European Geophysical Society. pp. 73-82. 